\title{
Probanza de méritos y servicios de Francisco Altamirano y su padre, Juan Velazquez Altamirano AGI Charcas Legajo 80, 133 fs. (año 1596)
}

Transcripción de José Luis Martínez, Cecilia Sanhueza, Carolina Odone y Andrea Ruiz-Esquide

[f. 1r]

Muy poderosso señor don Francisco Altamirano vezino e rregidor perpetuo desta ciudad digo que me conuiene que Vuestra Alteza mande hazer ymformacion de oficio conforme a la nueua çedula de vuestra Real perssona de mis meritos y seruiçios que e fecho a vuestra alteza de diez años a esta parte en este rano señaladamente contra los yndios de Omaguaca Calchaqui Casauindo e los demas comarcanos que an estado rreuelados contra Vuestra Real corona los quales con fuerca de armas ympedian la entrada trato e comercio de la prouincia de Tucuman con este reino de manera que para poder entrar a la prouincia de Tucuman e salir della a esta era nescesano escolta de veinte soldados bien pertrechados e visto por vuestro pressidente e oydores el daño que los dichos yndios hazian para la conquista y allanamiento dellos enuiaron all capitan Martin de Almendras vezino desta ciudad con mas de trecientos soldados y auiendosse aliado y convocado de vno los yndios apatamas omaguacas casauindos y calchaquies mataron all dicho capitan Martin de Almendras y a Joan de Cianeas encomendero de los yndios omaguacas e parte de los dichos soldados se passaron a la gouernacion de Tucuman retirandosse a ella despues de lo qual se encargo all capitan Pedro de Çarate la jornada e poblacion del valle de Jujuy adonde fue y en su compañia //

\section{[f. 1v]}

Gaspar de Roxas y el capitan Cristoual Barua de Aluarado que tenian yndios encomendados en los terminos del dicho ualle y estando poblados auiendo ido el dicho capitan Pedro de Çarate a pedir socorro de gente all gouernador de Tucuman los dichos yndios mataron al dicho capitan Cristoual Barua y la demas gente de suerte que se despoblo el dicho pueblo por esta ocasion se salieron a esta proumaa con gran rriesgo los dichos capitan Pedro de Çarate y Gaspar de Roxas continuando los dichos yndios los asaltos y enboscadas contra los españoles matando muchos los que yuan a conquistarlos valiendosse de los yndios de Calchaqui e de los de Viltipoco yndio muy sagaz e uelicosso que a causado muchos estragos e muertes a los españoles y estando en el estado tan trabajosso e peligrosso aquella tierra fue proueido por corregidor de la proumc $;$ a de Atacama el capitan Joan Uelasquez Altamirano mi padre el qual como tan leal uasallo de vuestra alteza procuro traer de paz los dichos yndios e rreduzirlos al conocimiento de la santa fee catholica y al seruiçio de vuestra alteza $y$ evitar los peligros e daños que causauan por medio de los caciques de su encomienda e para que ouiese efeto el subjetarlos me ymbio el dicho capiton Joan Velasquez Altamirano mi padre a tratar de susodicho all dicho ualle de Omaguaca Casauindo e Jujuy exponiendome a qualquiera //

\section{[f. 2r]}

peligro y rriesgo de la uida en seruiçio de vuestra alteza y con la buena diligencia e cuidado con que procedi traxe de paz all dicho Viltipoco y a sus yndios e a los de Omaguaca y a todos los demas que estauan aleados que auian caussado las dichas muertes e ympedian el passo y comercio de ambas prouincias de Tucuman y desta e para mas allanarlos y asegurar la paz saque los yndios principales anssi de Cassauindo como de Omaguaca de sus tierras donde estauan fortalecidos e de donde hazian los dichos daños e los traxe a esta corte y por vuestra alteza auiendo pedido perdon los dichos yndios se lo concedio con que se boluieron a sus tierras e desde entonces se allanaron y an quedado de paz en lo qual serui a vuestra alteza como vuestro vasallo en cassos de mucha ymportancia a vuestro red seruiçio y bien comun de paz fle la dicha prouincia de Tucuman en que hize y el dicho mi padre muchos gastos y espenssas y en excussables de nuestra hazienda sin ayuda de costa de vuestra real hazienda continuando con la solicitud nescessaria y trabajo de mi persona all seruiçio de vuestra alteza hasta que ubiesse $e$ l efeto que dicho tengo hallandome lo mas del tiempo que duro el traer los dichos yndios de paz en muchos peligros trabajos y riesgo de la uida con mis armas y cauallos procediendo en todo con el orden e lustre 
que deuia como notorio hijodalgo licuando a mi costa presseas de mucha estimacion //

\section{[f. 2v]}

para por estos medios atraer a los dichos yndios a la paz la qual guardan el dia de oy sin se auer aleado ni reuelado ni fecho los daños que solian hazer antes de la dicha pacificacion por que deuo ser remunerado por vuestra real perssona atento la calidad de los dichos seruiçios y de mi perssona y que estoy sumamente pobre e nescessitado como es notorio y depender de mi la sustentacion de doña Ysabel Brauo mi madre y quatro hermanas donzellas y dos hermanos por no auer quedado vienes patrimoniales por muerte del dicho mi padre de que poderse sustentar que el repartimiento de yndios de la prouincia de Atacama en que por muerte del dicho mi padre subcedi conforme a la ley de la subsecion como su hijo mayor legitimo no a sido de aprouechamiento alguno en todo el tiempo que lo emos posseido el dicho mi padre e yo porque nunca an tributado cossa que sea de algun prouecho e los mas yndios de dicho rrepartimiento no estan rreducidos ni siruen y anssi no es de ninguna conssideracion e para que con mas justificacion se me haga merced se deue conssiderar ansi mesmo los antiguos meritos e calificados seruiçios del dicho Joan Velasquez Altamirano mi padre pues conforme a vuestras leyes rreales la gratificacion //

\section{[f. 3r]}

de los seruiçios de los padres se deue hazer a sus hijos decendientes mayormente siendo tan señalados em [sic] particular por ser vno de los que prendieron a Egas de Gusman all tiempo que se aleo contra vuestra rreal corona en la villa ymperial de Potossi estando el tirano entre mucha gente de sus cecuac. es poniendosse el dicho mi padre a mucho rriesgo de la uida y guardo all dicho Egas de Gusman hasta tanto que se hizo justicia del e de los demas que le seguian auiendo sido presso por ellos el dicho mi padre e padescido muchos trabajos siendo despojado de su hazienda y armas con que se acauo la dicha tirania rressidiendo el dicho mi padre en la didha uilla de Potossi todo el tiempo que asistio en ella el mariscal Alonso de Aluarado acompañandole saliendo a prender a muchos de los delinquentes fuera de la dicha villa adonde lleuo presso a Joan de Santa Cruz e otros muchos que con el estauan aliados haziendo en esto el dicho mi padre muchas costas de su propia hazienda en que gasto mucha cantidad de pços de oro y continuando vuestro real seruiçio despues desto por nueua que ubo del alzamiento de Francisco Hernandez Giron en la ciudad del Cusco acudio el dicho mi padre con el dicho mariscal con sus //

\section{[f. 3v]}

armas y cauallos contra el dicho tirano e se hallo en la batalla que se dio en Chuquinga donde fue desbaratado el dicho mariscal y en esta ocassion fue muy maltratado e rouado el dicho mi padre y auiendosse escapado della fue por muchos despoblados a rriesgo de su perssona en busca de vuestro real exercito y junto el y el capitan Gomez de Solis fueron debaxo del estandarte real y se hallaron en el desbarate que hizieron los tiranos en la ciudad de Arequipa e despues estubo en el Desaguadero con la guarnicion e gente de guerra que alli estuuo guardando aquel passo hasta que el dicho Francisco Hernandez fue desvaratado en la batalla de Pucara despues de lo qual auiendo estado los yndios de Atacama veinte e dos años de guerra y aleados y que auian muerto muchos españoles y que ympedian con fuerza de armas el camino de Chile los traxo y rreduxo a la paz licuando sus amigos a la dicha prouincia en que gasto mucha suma y cantidad de pessos de oro e hizo poblar en el camino rreal un pueblo que se llama Toconao con que se a conseruado la paz y aunque el marques de Cañete vissorrey que fue destos reinos por los dichos seruicios //

\section{[f. 4r]}

encomendo all dicho mi padre los dichos yndios para podellos sustentar e tener de paz le dio dos mili pessos de salario con titulo de corregidor y estubo solo año y medio en el exercicio del dicho oficio y no solo gasto el dicho salario pero mucho mas de su hazienda en la conquista y pacificacion dellos y despues aca siempre an hecho amenazas de alcarsse e lo procuraron quando mataron al capitan Barua de Aluarado e por la buena diligencia e zelo del dicho mi padre con dadiuas y buenas persuaciones y tratamientos los conseruo siempre en la paz sustentandoles doctrina y vn sacerdote que los cateticaua [sic] y bautizaua como se a hecho y haze hasta el dia de oy sin compelerlos ni apremiarlos a pagar tributos algunos por ser la pretencion principal de rreduzirlos assentarlos y dotrinarlos ultra de que el dicho mi padre ha substanodo [sic] con el lustre de cauallero hijodalgo cassa e vezindad en esta corte que es frontera subs-tentando armas y cauallos e 
teniendo cassa poblada saliendo muchas vezes della a jornadas que vuestro pressidente a hecho contra los chiriguanaes que an estado de guerra y en otras ocassiones que se le an encargado salir a corredurias contra los dichos yndzos //

[f. $4 \mathrm{v}$ ] por ser honbre de confianza a su costa sin ser ayudado de vuestra rreal hazienda acudiendo con la diligencia necessaria a otras partes donde le a sido mandado por vuestro pressidente y oidores de'suerte que ansi en la paz como en la guerra emos acudido a vuestro red seruiçio el dicho mi padre e yo con toda puntualidad sin auer desseruiçio ni halladonos en motin alguno contra vuestra real corona sino siempre como vuestros leales vasallos zelossos de vuestro rreal seruiçio debajo de vuestro rreal estandarte como dicho es por lo qual y teniendo conssideracion a los dichos seruiçios y a que el rrepartimiento de Atacama hasta agora no a rentado cossa alguna y que no puede sustentar con el sola mi perssona quanto mas la de mi madre e quatro hermanas y dos hermanos segun la calidad de nuestras personas a vivira alteza suplico mande se rresciua ymformacion de oficio de todo lo que dicho es conforme a la nueua çedula de vuestra real perssona despachada para este efeto con citacion de vuestro fiscal y fecha se de el parecer por vuestro pressidente y oidores segun que se dispone por la dicha çedula para que constando//

\section{[f. 5r]}

a vuestra real perssona de los seruicios del dicho mi padre y mios en cassos tan señalados e ymportantes se sirua hazerme mercedes como a su vassallo benemerito de quatro mili pessos de rrenta en vuestra rreal caxa o en yndios de los que uacareri en esta prouincja haziendole yo dexaçion de los atacama que por fin y muerte del dicho mi padre tengo por mi uida sin otros uienes muebles ni rraizes mas que las cassas de nuestra morada que son de poco prescio juntamente con lo qual cabe en mi qualquiera otra merced que vuestra real perssona fuere seruicio hazerme de oficio y cargos de corregimientos e otros cargos de onor y aprouechamientos con lo qual se despache y embie la dicha ymformacion y parecer a vuestra real perssona y vuestro rreal conssejo de las yndias segun que lo dispone la cbcha vuestra real çedula donde yo ocurra a los conseguir con efeto e pido justicia para ello etc. el liçenciado Antonio de Escobar don Francisco Altamirano. [al margen: decreto]

Hagasse de oficio ante el oydor y por semanero con citacion del fiscal de su magestad //

\section{[f. 5v]}

En la ciudad de La Plata a nueue dejullio de mili e quinientos e nouenta e seis años los señores pressidente y oidores proueyeron lo decretado de susso pressente el señor fiscal a quien cite Joan de Lossa.

[al margen: juramento]

En la ciudad de La Plata a quinze dias del mes dejullio de mill y quinientos e nouenta e seis años el señor liçenciado Joan Diaz de Lopidana oydor semanero desta rreal audiencia para la ymformacion que s.e a de hazer de oficio de pedimento de don Francisco Altamirano hizo traer e parescer ante si a don Fernando de Çarate cauallero del auito de Santiago vezino feudetario [sic] desta ciudad y a Diego Hernandez de Castro e Joan Fernandez de Castro moradores en ella de los quales y de cada uno dellos rresciuio juramento e lo hizieron a dios y a la cruz en forma de derecho so cargo del qual prometio de dezir uerdad diziendo a la fuerga y conclussion del dicho juramento si juro y amen ante mi Joan de Lossa. En la ciudad de La Plata a diez y siete //

\section{[f. 6r]}

dias del mes dejullio de mill y quinientos y nouenta e seis años el señor liçenciado Joan Diaz de Lopidana oydor semanero para la dicha ymformacion hizo traer e parescer ante si a Francisco de Chaues corregidor del partido de Omaguaca Fustel Sanchez de Lada capitan Melchor de Rodas Gaspar Rodriguez procurador de caussas en esta corte Joan Perez Montañez el uiexo y Francisco de Ojeda moradores en esta ciudad de los quales y de cada uno dellos rreciuio juramento e lo hizieron a dios y a la cruz en forma de derecho so cargo del qual prometieron de dezir uerdad diziendo a la fuerga y conclucion del dicho juramento si juro y amen ante mi Joan de Lossa.

[al margen: juramento]

El dicho Joan Fernandez de Castro auiendo jurado segun derecho e siendo preguntado dixo lo siguiente: Preguntado si conoce a don Francisco Altamirano vezino y rregidor desta ciudad y de que tiempo y 
si conocio a Joan Uelasquez Altamirano su padre si saue que seruiçios ayan fecho a su magestod en que ocassiones como y quando.

Dixo que este testigo conoce al dicho don Francisco Altamirano de mas de quinze años y conocio //

al dicho Joan Uelasquez Altamirano su padre de mas de quarenta años a esta parte e conoce all doctor don Geronimo de Touar e Montalbo fiscal de su magestaa en esta rreal audiencia de La Plata y que lo que saue agerca de lo que se le pregunta es que en esta prouincia fue publico e notorio aora ueinte y treinta la poblacion que fueron a hazer en las prouincias de Calchaqui e Omaguaca los capitanes Martin de Almendras Pedro de Çarate y el capitan Barua de Aluarado e otras perssonas en diferentes tiempos por orden e mandado de los señores Pressidente y oidores desta real audiencia y este testigo uio entrar a algunos de los susso dichos en las dichas jornadas con gente de guerra por que los yndios de la dicha prouincias [sic] aun no estauan conquistados y ansi en la dicha conquista los dichos yndios mataron all dicho capitan Martin de Almendras y all capitan Barua de Aluarado y al capitan Joan de Qiancas e a otros muchos soldados y gente principal por ser los dichos yndios de los mas velicossos y astutos [testado: de] en guerras que ay en esta tierra y rrespeto de no se poder conquistar los dichos//

\section{[f. 7r]}

yndios e prouincjas y muerte de tanta gente los pueblos que se auian poblado se despoblaron e los dichos yndios se quedaron como de antes y de tal manera se encarnizaron contra los españoles que tenian los caminos e passos desta prouincja a la de Tucuman e Paraguay çerrados de manera que si no era juntandosse quinze y veinte soldados bien aderezados y muy a la ligera no podian entrar sino era con grandissimo rriesgo de las uidas y aun con la dicha preuencion quedauan algunos hazia Cassauindo muertos por los dichos yndios hasta abra ocho o nueue años poco mas o menos que entro el gouernador Joan Ramirez de Uelasco y este testigo con el y hasta este dicho tiempo todavia los dichos yndiqs andauan como de antes aunque algunos dellos respeto de la dicha preuencion y de que cada dia yuan entrando gentes desta prouiñcia se auian retirado al ualle de Omaguaca donde la mayor parte dellos estauan fortalecidos teniendo por capitan general a don Francisco Viltipoco yndio natural de Atacama que este testigo conocio e trato al qual este testigo saue que el dicho don Francisco Altamirano viniendo a solo versse con el desde la prouincia de Atacama //

\section{[f. $7 \mathrm{v}]$}

donde era corregidor el dicho Joan Uelasquez Altamirano su padre trato con el de que saliesse de paz e que los señores pressidente y oidores desta rreal audiencia le perdonarian sus ynso-lencias e muertes que sus yndios auian hecho a españoles que auian entrado a esta tierra e salido de la de Tucuman e con su buena yndustria diligencia e con algunas dadiuas y presseas que dio el dicho don Francisco Altamirano al dicho Uiltipoco e a otros caciques y principales sus sequaces los traxo e rreduxo a paz de manera que saco a algunos dellos en señal della a esta rreal audiencia donde este testigo los uio mediante lo qual e la buena diligencia del dicho don Francisco la tierra quedo de paz y tan llana que vn hombre solo puede entrar en la dicha prouincia de Tucuman y Paraguay y el camino que se solia caminar que llaman el camino de la quebrada le dexaron e se passaron all ualle de Omaguaca donde como dicho tiene estaua el dicho Uiltipoco y su gente y este testigo passo por el e hablo al dicho Uiltipoco el qual con sus yndios le siruio e dio //

\section{[f. 8r]}

yndios para que le guiassen por que aun la tierra e caminos no estauan bien abiertos e lo propio hizieron a otras muchas perssonas que entrauan e salian a la dicha prouincia y que a ssido lo susso dicho caussa de que aya tratos y contratos de mucha calidad y cantidad de las dichas prouincias a estas y de las del Brassil y Chile como es notorio en lo qual saue este testigo que el dicho don Francisco Altamirano a hecho muy particular seruiçio a su magestad y digno de remuneracion por lo que dicho tiene e porque el dicho don Francisco Altamirano a quedado y esta muy pobre e tiene muchas hermanas y hermanos todos por cassar y a su madre doña Ysabel Brauo que todos padescen muchas necesidades por ser muchos y poca hazienda porque aunque el dicho don Francisco Altamirano heredero como hijo mayor el rrepartimiento de yndios de Atacama no a tenido ningun aprouechamiento de conssideracion del porque siempre el susso dicho y el dicho su padre an ydo contemporissando con los dichos yndios // 


\section{[f. 8v]}

sin apremiarlos a que pagassen tassa por tenellos contentos y no apremiados para que man- tuuiesen la paz en que el dicho don Francisco Altamirano los auia puesto e dexado todo con zelo cristiano e de seruir la de su magestad e como su leal uasallo y es digno merecedor que su magestad le rremunere los dichos sus seruiçios y del dicho su padre que fueron tan notorios e publicos en este reino.

Preguntado si saue o a oido dezir que el dicho don Francisco Altamirano o el dicho Joan Uelasquez Altamirano su padre ayan desseruiçio en cossa alguna a el rrey nuestro señor o ydo contra su real corona o dado ayuda para ello.

Dixo que no saue ni a oydo dezir cossa alguna de lo que se le pregunta antes saue lo contrario por lo que tiene dicho.

Preguntado si saue que los dichos don Franosco Altamirano o el dicho Joan Uelasquez Altamirano su padre ayan resceuido algun premio estipendio o galardon o ayuda de costa de la caxa real $o$ en otra manera por razon de los dichos seruiçios dixo que siempre entendio este testigo //

\section{[f. 9r]}

que los susso dichos siruieron a su magestad en las ocassiones que dichas tiene sin auer rresceuido ayuda de costa ni otro estipendio de la hazienda rea todo con mucho lustre de sus perssonas y que no saue que el dicho Joan Velasquez Altamirano aya resceiudo otra cossa por rrazon de los dichos sus seruiçios mas del repartimiento de yndios de Atacama como dicho tiene que estos an sido de tan poco prouecho como lo tiene declarado e que esto que dicho tiene es la uerdad so cargo del juramento que hizo e firmolo de su nombre y dixo ser de hedad de mas de quarenta y cinco años e no le toca ninguna de las generales de la ley Joan Fernandez de Castro ante mi Joan de Lossa.

\section{[al margen: Diego Fernandez de Castro]}

El dicho Diego Fernandez de Castro vezino desta ciudad auiendo jurado segun derecho e siendo preguntado dixo lo siguiente:

Preguntado si conoce a don Francisco Altamirano vezino y regidor desta ciudad y si conocio a Joan
Uelazquez Altamirano su padre y si conoce all fiscal //

de su magestad en esta real audiencia de La Plata e si saue en que ocasiones ayan seruiçio a su magestad los dichos don Francisco Altamirano e Joan Uelasquez Altamirano como y en que tiempo.

Dixo que este testigo conoce all dicho don Francisco Altamirano de mas tiempo de ueinte años a esta parte y conocio all dicho Joan Velaszquez Altamirano su padre de quarenta e quatro años a esta parte poco mas o menos y conoce all doctor don Geronimo de Touar e Montaluo fiscal de su magestad en esta real audiencia de La Plata y que lo que saue acerca de lo que se le pregunta por la peticion del dicho don Francisco Altamirano es que a sido publico en este reino que los señores pressidente y oidores desta rreal audiencia que era a la sazon que passo lo que se le pregunta embiaron all capitan Martin de Almendras a pacificar las prouincias en la pregunta contenidas contenidas [sic] e subçedieron las muertes y estragos en ella contenidos y anssi mesmo fue publico //

\section{[f. 10r]}

y notorio que el capitan Joan Uelasquez Altamirano fue proueido por corregidor de Atacama y que su hijo don Francisco Altamirano fue e traxo de paz all yndio Viltipoco en la dzcha peticion contenido como todo paresçera por el titulo e merced que se le hizo all dicho Joan Uelasquez Altamirano a que este testigo se rrefiere y que en lo que toca a los seruiçios que el dicho Joan Uelasquez Altamirano hizo a su magestad saue este testigo porque se hallo pressente que el dicho Joan Uelasquez Altamirano fue uno de los primeros que prendieron a Egas de Gusman que estaua alterado contra su magestad $y$ su seruiçio en la uilla y asiento de Potossi con mucha gente e estubo presso con mucho cuydado e uigilancia hasta que se hizo justicia del dicho Egas de Gusman y sus sequages que fue un [testado: o] muy importante seruiçio que se hizo a su magestad auiendole costado mucha parte de hazienda e saue y uio este testigo que el dicho Joan Uelasquez Altamirano siempre asistio en la dicha //

\section{[f. 10v]}

Villa de Potossi con el mariscal Alonso de Aluarado que estaua haziendo el castigo de los alterados que 
auia en la dicha uilla y esta ciudad y estuuo siempre acompañando el estandarte real e salio con el dicho mariscal Aluarado despues de auer dexado pacifica toda esta tierra para la ciudad del Cusco por nueua que se tubo de el alzamiento de Francisco Hernandez Giron e saue que se hallo en la batalla de Chuquinga con el dicho mariscal donde este testigo tambien yua e saue fue desuaratado el dicho mariscal en esta refriega con su gente donde uio que el dicho Joan Uelasquez Altamirano salio rovado con la demas gente y fue publico e notorio se hallo en la ciudad de Arequipa con el capitan Gomez de Solis contra los aliados del dicho Francisco Hernandez y despues se hallo ansi mesmo en la batalla de Pucara el dicho Joan Uelasquez Altamirano adonde fue desbaratado el dicho Francisco Hernandez Giron e su gente auiendose hallado primero en el Desaguadero e se dio la vatalla que //

\section{[f. 11r]}

dicho tiene de Pucara en todo lo qual siruio como muy buen soldado y leal uassallo de su magestad con armas y cauallos y con mucho lustre de su perssona y en todo lo que se ofrescio del seruiçio de su magestad acudio con la puntualidad y rretitud que deuia e saue este testigo que quedo muy pobre e dexo muchas hijas por cassar e hijos e por ser como es gente noble e principal padescen nescessidad por no conocerles el testigo vienes mas de unas cassas en que biuen e ser las costas e gastos desta tierra muchos e tener los susso dichos obligacion de sustentar mucha onrra por ser gente tan principal como dicho tiene y que aunque tiene algunos yndios en Atacama son de poco prouecho por estar lexos e los mas dellos no querer seruir y que son dignos los dichos don Francisco Altamirano madre hermanas y hermanos que su magestad les haga merced para se poder sustentar honrradamente y casarsse las donzellas.

\section{[f. 11v]}

Preguntado si saue este testigo o a oydo dezir que los dichos don Francisco Altamirano y Joan Uelasquez Altamirano su padre ayan desseruido a su magestad en alguna cossa por si o por ynterpossitas perssonas o ydo contra su real corona en alguna manera:

Dixo que nunca a entendido ni sauido lo que se le pregunta antes saue lo contrario por lo que dicho tiene.
Preguntado si saue este testigo que por razon de los dichos seruiçios los dichos Joan Uelasquez Altamirano y don Francisco Altamirano su hijo ayan resceuido alguna rremuneracion o estipendio de la caxa real o se le aya dado alguna cossa equibalente.

Dixo que no saue ni a oydo dezir que los susodichos ayan tenido remuneracion de su magestad ni de su rreal hazienda por razon de los dichos seruiçios ni tenido ayuda de costa en el tiempo que siruieron por auer sido a la suya mas de tan solamente los yndzos de Atacama que son de poca consideracion como dicho tiene e saue que su magestad en hazer //

\section{[f. 12r]}

merced all dicho don Francisco Altamirano por sus seruiçios e los del dicho su padre y a su madre hermanas y hermanos descargara su real conciencia por las caussas y razones que tiene dichas lo qual dixo ser la verdad y lo que saue y entiende deste casso y que este testigo tiene dicho otro dicho acerca de los testigos seruicios del dicho Joan Uelasquez Altamirano y que lo que alli tiene dicho y esto se entienda ser una mesma cossa e no contradezirsse en cossa alguna porque la uoluntad deste testigo no es mas de dezir uerdad e lo firmo de su nombre e dixo ser de hedad de setenta e quatro años poco mas o menos e no le tocan las generales de la ley leyossele su dicho ratificosse en el Diego Fernandez de Castro ante mi Joan de Lossa.

\section{[al margen: Francisco de Oxeda]}

El dicho Francisco de Ojeda auiendo jurado segun derecho e siendo preguntado dixo lo siguiente:

Preguntado si conoce al dicho don Francisco Altamirano vezino y rregidor desta //

\section{[f. 12v]}

ciudad y si conocio a Joan Uelasquez Altamirano su padre e si conoce all doctor don Geronimo de Touar e Montaluo fiscal del rey nuestro señor en esta real audiencia desta ciudad de La Plata y si saue en que cossas e cassos los dichos don Francisco Altamirano y Joan Uelasquez Altamirano su padre y en que ocassiones como y quando ayan seruiçio a su magestad en estos reinos.

Dixo que este testigo conoce all dicho don Francisco Altamirano desde su nacimiento e conocio ansi 
mesmo al dicho Joan Uelasquez Altamirano su padre de mas tiempo de quarenta años a esta parte y conoce all señor fiscal de su magestad e que lo que saue acerca de lo contenido en la peticion del dicho don Francisco Altamirano es que este testigo siempre a oydo dezir por cossa publica e notoria todo lo contenido en la dicha peticion que le fue leyda de berbo ad verbum lo qual oyo dezir a las mesmas perssonas que se hallaron en las ocassiones que dize la peticion //

\section{[f. 13r]}

y que ansi el dicho don Francisco Altamirano como el dicho Joan Uelasquez Altamirano su padre siruieron a su magestad con sus armas y cauallos y criados a su costa con mucho lustre I de sus perssonas por ser como es y fue el dicho su padre gente muy principal en este reino y que saue que por no tener ni auer dexado el dicho Joan Uelasquez Altamirano hazienda I suficiente padescen nescessidad el dicho don Francisco Altamirano y doña Ysauel Brauo su I madre por tener como tiene quatro hermanas donzellas que no se an podido cassar por no tener con que e tres hermanos todos gente muy principal i onrrada $\mathrm{y}$ entiende este testigo y tiene por muy cierto son dignos de la merced que su magestad fuere seruido de hazerles por lo que dicho tiene. //

\section{[f. $13 v]$}

Preguntado si saue este testigo o a oido dezir que los dichos don Francisco Altamirano y Joan Uelasquez Altamirano su padre ayan receuido alguna ayuda de costa de la real hazienda e dadole renuciacion [sic] por los dichos seruicios.

Dixo que no saue ni entiende este testigo que los susso dichos ayan sido remunerados de la $I$ hazienda real por razon de lo que dicho tiene mas de que los yndios de Atacama que estan en cabeça del dicho don Francisco Altamirano se le dieron all dicho su padre en alguna remuneracion y estos los tiene por de muy poco prouecho por estar muy lexos desta dicha ciudad e no querer seruir por estar en el camino de Tucuman tierras desiertas y de poca conssideracion y esto que dicho tiene dixo ser la uerdad de lo que saue acerca de lo que se le a preguntado so cargo de juramento que fecho tiene e lo firmo de su nombre e dixo ser de hedad de mas de setenta años e no le tocan ninguna de las preguntas generales de la ley siendole leydo su dicho se ratifico en el Francisco de Oxeda ante mi Joan de Losa. // [f. 14r]

[al margen: Testigo capitan Melchor de Rodas]

El dicho capitan Melchor de Rodas vezino de las fronteras de Tomina e poblador dellas testigo jurado e siendo preguntado dixo lo siguiente:

Preguntado si conoce all dicho don Francisco Altamirano e si conocio a Joan Uelasquez Altamirano su padre e si conoce all doctor don Geronimo de Touar e Montaluo fiscal de su magestad en la real audiencia de La Plata e si saue en que cossas y casos tiempo y ocassiones los duchos don Francisco Altamirano y el dicho Joan Uelasquez Altamirano ayan seruiçio a su magestad en este reyno dixo que conoce all dicho don Francisco Altamirano desde que nacio y conoce all dicho su padre desde que este testigo tubo entendimiento y razon que abra mas de sesenta y quatro años y conoce al dicho fiscal de su magestad desde que uino nombrado por tal y entro en esta real audiencia con el dicho su oficio y que lo que saue es que el dicho don Francisco Altamirano fue y saco de paz a los yndios omaguacas por orden e mandado de Joan Velasquez Altamirano su padre que a la sazon era corregidor de Atacama e los lleuo a la villa de Potossi a Joan Ortiz de Çarate que era justicia mayor en esta prouincia y el dicho //

\section{[f. $14 \mathrm{v}]$}

Joan Ortiz de Çarate ymbio a llamar a este testigo que estaua en la dicha uilla de Potossi i le dixo que aquellos caciques que auia sacado el dicho don Francisco Altamirano le dezian e prometian de asegurar el camino que va a las prouincias de Tucuman e que harian vn tambo en vna parte comoda donde darian comida y auiarmVnto a los que fuessen y uiniessen a la dicha proumaa de Tucuman y este testigo le dixo que era vna cossa de gran ymportancia y que conuenia mucho porque hasta entonces que auia mas de treinta e tantos años sauia este testigo que hazian grandes muertes y daños en los que ivan e venian a las dichas prouincias y que era en tanta manera que si no era ueinte y treinta hombres juntos no osauan entrar ni salir e muy aperceuidos porque se acuerda este testigo que mataron una uez diez o doze hombres y que saue anssi mesmo que yendo el capitan Martin de Almendras vezino desta ciudad con mas de cien hombres a conquistar e pacificar aquella tierra le mataron apartandosse de su gente y que ansi mataron a Qiencas encomendero de los dichos yndios y a otras // 


\section{[f. 15r]}

muchas perssonas y que despues que el dicho don Francisco Altamirano los saco de paz no a oydo ni entendido que ayan muerto a ninguna perssona antes que an salido y salen y dan auiamento y comidas a los passaxeros y que en esto saue este testigo que hizo grandissimo seruiçio all rey nuestro señor y a toda esta tierra y a la de Tucuman y que no supo ni entendio que se le dio all dicho don Francisco ni all dicho su padre ayuda de costa y que si se le diera este testigo lo supiera por la comunicacion y trato que tubo con los susso dichos y que por esto e ser el dicho don Francisco persona tan hijodalgo notorio y auer quedado tan pobre con vna madre y con quatro hermanas donzellas e dos hermanos es justo que su magestad le haga mucha merced y en mucha cantidad por las razones que dichas tiene y que en lo que toca a los seruiçios del dicho Joan Uelasquez Altamirano saue este testigo por cossa notoria que el susso dicho fue uno de los principales que prendieron a Egas de Gusman en la villa de Potossi que estaua alçado contra la real corona y que tiene por cossa cierta que le guardaria como a uno de los soldados de mas lustre //

\section{[f. 15v]}

y confianza que en aquella villa auia en el seruiçio de su magestad y que saue que despues fue aprender delinquentes como hombre de tanta confianza como dicho tiene e saue que trajo a la dicha uilla ymperial de Potossi all capitan Santa Cruz y alli se hizo justicia del e ayudo a limpiar la tierra de traidores de suerte que quedo pacifica y en ello siruio notablemente como hombre muy principal que era e que esta satisfecho que fue a su costa porque era hombre de muchas prendras [sic] y posible todo con mucho lustre de su perssona como hombre tan valerosso y principal y saue ansi mesmo este testigo por auerse hallado a todo pressente que el dicho Joan Uelasquez Altamirano salio de la dicha villa de Potossi muy bien aderesçado de armas y cauallos y criados del seruicio de su persona de yndios e negros e fue acompañando al mariscal don Alonsso de Aluarado que se tubo noticia de que Francisco Hernandez Giron estaua alçado en la ciudad del Cusco y salido para la de Los Reyes //

\section{[f. 16r]}

contra la audiencia real y que en toda la jornada uio este testigo que el dicho Joan Velasquez fue siruiendo como muy escogido soldado hasta que se llego al ualle de Chuquinga donde el dicho tirano estaua y que uio que entro en la batalla que alli se dio donde fue desbaratado el dicho mariscal de donde salio rovado el dicho Joan Velasquez Altamirano y este testigo quedo presso en el campo enemigo y despues supo este testigo que fue por muchos despoblados el dicho Joan Velasquez Altamirano y que se hallo en la ciudad de Arequipa con el capitan Gomez de Solis y saue anssi mesmo que despues se hallo con el dicho capitan Gomez de Solis en el Desaguadero guardando aquel paso que es muy ynportante y supo este testigo en el campo de su magestad despues que entro en el que fue diez o doze dias o quinze antes que se diesse la batalla del Pucara adonde este testigo se hallo debaxo dell estandarte real que el dicho Joan Uelasquez Altamirano auia andado muy en seruicio del rey nuestro señor y echo lo que tiene dicho e dada //

\section{[f. 16v]}

la dicha batalla se hallo en el Desaguadero con el dicho Gomez de Solis guardando aquel passo con mucha vigilancia e cuidado y en todo siruio notablemente porque era muy valiente soldado e uno de los mejores arcabuzeros que auia en este reino.

Preguntado si saue este testigo o a oydo dezir que el dicho don Francisco Altamirano o el dicho su padre ayan desseruido a su magestad en cossa alguna e no acudido como deuen a su real seruicio dixo que nunca a entendido ni sauido que los susso dichos ayan ido en cossa ninguna contra el seruicio de su magestad sino seruidole con mucha limpiessa e notablemente como dicho tiene e que si ouiera otra cossa este testigo lo supiera por auerse hallado sienpre en las ocassiones que tiene dichas.

Preguntado si saue este testigo que el dicho don Francisco Altamirano o el dicho su padre ayan resceuido algun estipendio o ayuda de costa de la hazienda real por razon de los dichos sus seruicios y en remuneracion dellos.

Dixo que no saue que ayan sido remunerados los susso dichos por que el repartimiento //

\section{[f. 17r]}

de Atacama que le fue encomendado fue y es de tan poco prouecho que antes con el a seruido mucho mas a su magestad $y$ tenido mucho gasto por mantenelles 
en paz y que no se aluorotassen e dar alli auissos de las cossas de Chile y de los herejes yngleses que a sido una cossa de mucha ymportancia no solamente saue este testigo que no a cobrado la tassa por tenellos contentos para los efetos dichos e para la seguridad del camino de Chile mas antes saue que a gastado de la hazienda que aca tenia porque saue que uendio una chacara que vale oy quinze o ueinte mili pesos por mucho menos cantidad de lo que vale y que conforme a la calidad de su perssona e tantas hijas e hijos a quedado pobre i estos seruicios an sido e son dignos de remuneracion equivalente a ellos y estara bien la merced que su magestad hiziere all dicho don Francisco Altamirano aunque sea en seis mili pesos de renta por las caussas seruicios pobreza y neçeçidad que tiene referido y la calidad de su persona y esto que dicho tiene dixo este testigo ser la verdad de lo que saue so cargo del juramento //

\section{[f. 17v]}

en que se afirmo e ratifico e lo firmo de su nombre y dixo ser de hedad de setenta años poco mas o menos e no le tocan las generales de la ley Melchor de Rodas ante mi Joan de Lossa.

\section{[al margen: testigo]}

El dicho Gaspar Rodriguez procurador de corte en la real audiencia que en esta ciudad resside auiendo jurado segun derecho e siendo preguntado dixo lo siguiente:

Preguntado si conoce a don Francisco Altamirano vezino y regidor desta ciudad e de que tiempo y si conocio a Joan Uelasquez Altamirano e tiene noticia de los seruicios que an hecho en este reino a su magestad y en que cossas e ocassiones.

Dixo que este testigo conoce all dicho don Francisco Altamirano de mas de ueinte años a esta parte y conocio all dicho Joan Uelasquez Altamirano su padre de treinta e ocho años a esta parte e conoce all doctor don Geronimo de Touar y Montaluo fiscal de su magestad en la real audiencia que en esta ciudad resside y que lo que saue acerca de lo conthenido en la peticion en esta caussa pressentada dixo que //

\section{[f. 18r]}

este testigo uio que auiendo auido los daños e ynconuinientes caussados por los dichos yndios de Omaguaca Casauindo y Calchaqui esta real audiencia para la seguridad y allanamiento de todo ymbio all capitan Martin de Almendras con el numero de gente que el pedimento dize lo qual allano y apaciguo por los mejores medios que pudo y abrio y aseguro el camino que estaua serrado con las muertes robos e ynsultos causados por los yndios que dicho tiene el dicho Joan Velasquez Altamirano y don Francisco Altamirano su hijo entrando en sus tierras licuando de los caciques e yndios de Atacama de su encomienda que los atraxesse a la paz y quietud que conuenia tratar a los quales trayendo primero a obediencia del seruiçio de Dios nuestro señor e de su magestad traxo de paz los caciques e yndios de Omaguaca y otros que de mas de quarenta y ocho años a esta parte estauan aleados y reuelados sin auer querido dar la ouediencia a su magestad en lo qual padescio mucho riesgo de su perssona e desde entonces //

\section{[f. 18v]}

hasta agora esta llano y seguro el dicho camino y contratacion desta prouincia con la de las prouincias de Tucuman y este seruiçio fue muy principal e señalado como es notorio y en lo demas contenido en el dicho pedimento dize lo que dicho tiene en el capitulo antes deste y ansi es uerdad que auiendo ydo a la reformacion poblacion y allanamiento del ualle de Jujuy el capitan Pedro de Carate Gaspar de Roxas e otros vezinos los yndios de Casauindo apatamas y omaguacas fue publico los mataron una noche y este testigo saue por cossa cierta y publica que el dicho don Francisco Altamirano por orden e mandado del dicho Joan Uelazquez Altamirano su padre all tiempo e quando fue a tratar de los dichos medios e pazes con los yndios Viltipoco y Omaguaca licuaron muchas cossas de dadiuas de mucho prescio todo lo qual a tenido el buen subcesso que el capitulo del dicho pedimento refiere y dize y esto es cossa publica e notoria en esta prouincia e saue que el dicho Joan //

\section{[f. 19r]}

Velasquez Altamirano dexo pobres e con nescessidad a su muger e hijos por que el repartimiento de Atacama en que el dicho don Francisco Altamirano subcede es de muy poco aprouechamiento por que se an sobrelleuado con halagos e dadiuas antes que con pedirles tassa ni tributo mas de lo que ellos an querido dar por estar como estan poblados en tierra de guerra y que se an comunicado con los de Calchaqui y Omaguaca y los demas que an sido los caussadores de las muertes y daños que a dicho e los capitulos 
del dicho escrito refieren y tan solamente tienen por bienes las cassas de su morada que valdra hasta tres mili pessos con los quales es cossa ynpossible poder tomar estado quatro hijas donzellas que dexo sin los hijos varones ni podersse sustentar conforme a la calidad de sus perssonas y este testigo se hallo en la uilla de Potossi antes y all tiempo que Egas de Gusman maesse de campo de don Sebastian de Castilla se aleo contra el seruicio de su magestad en la uilla de Potossi y se apodero de toda la gente que en ella auia y mato al contador //

\section{[f. 19v]}

Francisco de Aluarado en cuya prission e de Francisco de Bergara se hallo el dicho Joan Uelasquez Altamirano y el capitan Martin de Almendras Gomez de Solis Joan Mendes e otros vezinos desta ciudad que estauan pressos por el dicho tirano en la dicha villa y se ocupo en velas y centinelas y en todo lo demas que conuino al seruiçio de su magestad hasta que esta prouincia quedo llana y debaxo de la real audiencia e los dichos tiranos castigados y hecho justicia dellos y auiendo uenido a la dicha uilla al castigo de la dicha reuelion el mariscal don Alonso de Aluarado con cornission de la real audiencia de los señores de la real audiencia de la chancilleria de la ciudad de Los Reyes el dicho Joan Uelasquez Altamirano estuuo con sus armas como leal uasallo de su magestad dandole fauor e ayuda nescesaria al dicho mariscal ocupandosse en todo lo que le era ordenado e mandado en aquellos negocios hasta que vino nueua del alzamiento y reuelion de Francisco Hernandez Giron //

\section{[f. 20r]}

y sus sequaces en la ciudad del Cusco contra los quales el dicho Joan Uelasquez Altamirano bien aderecado de armas y cauallos se ofrescio de nueuo al real seruiçio para que le ocupasse en todas las cossas de calidad tocantes all real seruiçio todo lo qual hizo en tiempo muy nescessario all real seruiçio desde donde fue debaxo del Real estandarte bien aderecado de armas y cauallos en busca del dicho Francisco Hernandez al ualle de Chuquinga donde se le dio uatalla por el campo real que lleuaua el mariscal donde este testigo oyo dezir a muchos de los que se hallaron en el ... el dicho Joan Uelasquez como perssona de obligacion es tan leal seruidor de su magestad hasta que fueron desuaratados por el dicho tirano y es publico e notorio que el dicho Joan Uelasquez Altamirano ayudo a guardar el passo del
Desaguadero con el capitan Gomez de Soliz que fue cossa muy inportante all seruicio real y caussa para que el enemigo fuesse como fue desuaratado en Pucara todo con mucho lustre de su perssona //

\section{[f. 20v]}

como buen cuallero hijodalgo y leal seruiçior de su magestad $y$ el año de çinquenta y siete que todauia auia gente belicossa que desasosegauan las poblaciones desta prouincia teniendo el liçenciado Altamirano hermano del dicho Joan Uelasquez Altamirano la tenencia y gouierno desta prouincia de los Charcas por orden del marques de Cañete Joan de Santa Cruz e otras gentes que se le auian allegado traian inquieta esta prouincia y el dicho Joan Uelasquez Altamirano con gente que lleuo como perssona de confiança le fue a prender a la prouincia de los Chichas e le trajo presso a la uilla de Potossi donde se hizo justicia del con lo cual quedo esta prouincia con sosiego e quietud e todo reduzido all real seruiçio de su magestad en lo qual y en todas las demas ocassiones que se an ofrescido all real seruiçio en paz y en guerra le a uisto acudir con mucha diligencia e puntualidad como tan celozo a las cossas del real seruicio. //

\section{[f. 21r]}

Preguntado si saue este testigo o a oydo dezir que el dicho don Francisco Altamirano o Joan Uelasquez Altamirano su padre ayan desseruido en cossa alguna al rey nuestro señor o ydo contra su real corona o dado ayuda para ello en qualquiera manera.

Dixo que nunca este testigo a sauido ni entendido ni oydo dezir que los susso dichos ayan desseruido a su magestad en cossa alguna antes saue lo contrario por lo que dicho tiene.

Preguntado si saue que por razon de los seruicios del dicho don Francisco Altamirano y Joan Uelasquez Altamirano su padre ayan resceuido de la hazienda real alguna ayuda de costa o estipendio en remuneracion dellos o se le aya dado alguna renta.

Dixo que no saue ni a entendido que los susso dichos ayan resceuido de la hazienda real cossa alguna ni que se les aya dado ayuda de costa ni otra renta alguna mas del repartimiento de yndios de Atacama que este es de muy poca conssideracion e prouecho en tal manera que por ser yndios mesclados con los de guerra y estar muy lejos desta ciudad nunca an 
sido tassados ni dan mas de lo que ellos quieren y que el dicho //

\section{[f. 21v]}

don Francisco Altamirano nunca ni el dicho su padre les an apremiado por mantenellos en paz antes les a dado dadiuas de sus haziendas por lo que dicho tiene por las quales razones saue este testigo que cabra en el dicho don Francisco Altamirano qualquier merced equivalente a los dichos seruiçios que el rey nuestro señor fuere seruiçio de le hazer e que esto que dicho tiene es la uerdad y lo que saue de lo que se le a preguntado so cargo del juramento que tiene fecho en que se afirmo e ratifico e firmo de su nombre e dixo ser de hedad de mas de çinquenta e çinco años e no le toca ninguna de las preguntas generales de la ley Gaspar Rodriguez ante mi Joan de Lossa.

\section{[al margen: Testigo Juan Perez Montañez]}

El dicho Juan Perez Montañez vezino desta ciudad testigo susso dicho auiendo jurado e siendo preguntado dixo lo siguiente:

Preguntado si conoce a don Francisco Altamirano vezino y regidor desta ciudad y si conocio a Joan Uelasquez Altamirano su padre difunto e si conoçe all doctor //

\section{[f. 22r]}

don Geronimo de Touar y Montaluo fiscal del rey nuestro señor en la real audiencia de La Plata y si saue en que cossas e cassos tiempos y ocassiones los dichos Joan Uelasquez Altamirano y el dicho don Francisco Altamirano su hijo ayan seruido a su majestad en estos reynos dixo que este testigo conoce all dicho don Francisco Altamirano e conocio a el dicho Joan Uelasquez Altamirano su padre difunto de mas de quarenta años a esta parte y all dicho su hijo de mas de ueinte e saue que el doctor don Geronimo de Touar y Montaluo es fiscal en esta dicha real audiencia por su magestad y lo que saue es que este testigo estando en esta ciudad oyo dezir los muchos estragos que los yndios omaguacas apatamas cassauindos y calchaquies hazian en el camino que ua de la prouincia de Tucuman matando tanta gente como mataron y a tantos capitanes que fueron a los allanar e pacificar por lo mucho que ymportaua all seruiçio de dios y de //

\section{[f. 22v]}

su magestad bien pro y utilidad de toda esta tierra que duro la dicha conquista mas de veinte e cinco años e uisto que conuenia poner remedio en cossa tan ymportante fue proueido por Corregidor de Atacama el dicho Joan Uelasquez Altamirano padre del dicho don Francisco Altamirano el qual para traer a la paz e ouediencia de su magestad a los dichos yndios embio a su hijo don Francisco Altamirano que los traxesse de paz con los mejores medios que pudiesse y con muchas dadiuas que fue publico lleuo para darles y halagarles el qual saco de paz los caciques principales que estauan reuelados y aleados e an mantenido la dicha paz hasta oy en que el dicho don Francisco Altamirano hizo muy gran seruiçio a su magestad e bien a toda esta prouincia porque por su ocassion estan los passos de Tucuman que ua desta tierra a la dicha prouincia muy llanos y seguros y se hallo auio para poder passar estos caminos e meresce el susso dicho //

\section{[f. 23r]}

gran remuneracion por este seruiçio por auer sido de tanta calidad como dicho tiene y estar el dicho don Francisco tan pobre que ni puede sustentar quatro hermanas donzellas que tiene y hermanos y una madre porque demas de que la hazienda que tienen es muy poca el repartimiento que tiene de Atacama es de tan poco prouecho que antes les caussa de gasto que no de aprouechamiento porque son yndios muy lejanos desta ciudad e que no acuden a pagar tassa ni a ello les apremia el dicho don Francisco Altamirano porque no se alcen ni reuelen por ser yndios muy uelicossos y ansi qualquier merced que su magestad le heziera aunque sea en cantidad de seis mili pessos sera equivalente a los dichos seruicios e la meresce el dicho don Francisco por su perssona e por los seruicios e meritos del dicho su padre que fueron muchos e muy notables [...]

\section{[f. 24v]}

Preguntado si saue este testigo que los dichos don Francisco Altamirano y el dicho su padre por razon de los dichos seruicios ayan resceuido de la real hazienda algun socorro o ayuda de costa o otra renta alguna en remuneracion dellos.

Dixo que no saue que ninguno de los suso dichos ayan resceuido cossa alguna // 


\section{[f. 25r]}

de la hazienda real por razon de auer seruido a su magestad en las ocassiones que tiene dichas mas del repartimiento de Atacama que como dicho tiene es de tan poca consideracion como lo tiene declarado todo lo qual dixo ser la uerdad so cargo del juramento que fecho tiene en que se afirmo y ratifico e no firmo por estar priuado de la vista corporal e dixo ser de hedad de ochenta años vno mas o menos e no le tocan ninguna de las preguntas generales de la ley ante mi Joan de Lossa.

\section{[al margen: Decreto]}

Don Francisco Altamirano de memorial jurado de lo que uale Atacama en cada un año en veinte e nueue de jullio de mill y quinientos y nouenta e seis.

En La Plata a ueinte y nueue de jullio de mili e quinientos y nouenta e seis años los señores pressidente e oidores proueyeron lo decretado de susso Joan de Lossa.

\section{[al margen: Testigo don Fernando de Çarate]}

El dicho don Fernando de Çarate cauallero del auito de Santiago vezino desta dicha ciudad testigo susso dicho auiendo jurado en forma //

\section{[f. 25v]}

deuida de derecho e siendo preguntado por la peticion pressentada por don Francisco Altamirano dixo que conoce all dicho don Francisco Altamirano de mas de treinta años a esta parte y ansimesmo conocio a Joan Velasquez Altamirano su padre vezino que fue desta dicha ciudad del mismo tiempo a esta parte e que saue que el camino de aqui a Tucuman a estado los años passados muy peligrosso e los yndios de guerra y aleados e que no se podia passar ni estar en la dicha pouincia sin fuerça de gente y armas de lo qual resultauan muchos daños muertes y robos y uisto por los señores pressidente y oidores desta real audiencia proueyeron al capitan Martin de Almendras vezino desta dicha ciudad para que fuese all castigo de los yndios de aquellas partes para que estuuiesse el dicho passo seguro e castigasse los dichos yndios reuelados con el qual fueron muchos soldados con el dicho capitan Martin de Almendras y uino nueua a esta dicha ciudad como los dichos yndios de guerra // [f. 26r]

auian muerto all dicho capitan Martin de Almendras y a Joan de Cianeas encomendero de los yndios omaguacas e despues de lo suso dicho saue este testigo que el virrey don Francisco de Toledo proueyo a el capitan Pedro de Çarate y le dio comission para que poblasse un pueblo de españoles en el ualle de Jujuy que es en el mismo camino de Tucuman para lo qual lleuo desta ciudad a algunas perssonas que fueron Crispoual Barua y Gaspar de Roxas vezinos desta dich a ciudad y en la dicha ocassion los cuchos yndios de guerra mataron all dicho capitan Crispoual Barua e a otros muchos que fueron en compañia del dicho capitan Pedro de Çarate e los dichos yndios despoblaron el dicho pueblo de Jujuy e passados algunos años despues de lo susso dicho los uirreyes que an ssido destos reynos proueyeron por corregidor all dicho Joan Velasquez Altamirano padre del dicho don Francisco Altamirano por corregidor de la prouincia de Atacama en la qual estuuo por tal corregidor diverssas vezes de donde embio all dicho don Francisco Altamirano su hijo para que procurasse sacar de paz a los yndios omaguacas y circunvezinos que etauan reuelados por medio de un cacique del dicho repartimiento de Atacama encomendado en el dicho Joan //

\section{[f. 26v]}

Velasquez Altamirano yndio muy velicosso que se auia retirado del dicho repartimiento de Atacama all de Omaguaca a quien respetauan los dichos yndios e los demas comarcanos que el dicho caçique se llamaua Viltipoco e por medio del dicho don Francisco Altamirano y el cuidado y diligencia e trabajo que pusso en la pacificacion de los dichos yndios saco a algunos caciques de paz e los traxo a esta real audiencia e visto por ella se les dio perdon de los delitos que auian cometido en el dicho ualle de Omaguaca Casauindo y Jujuy y en lo qual el dicho don Francisco Altamirano se pusso a mucho riesgo e mucho trabajo sin tener socorro ni ayuda de costa antes gastando lo que fue nesçessario de su hazienda despues de lo qual este testigo saue e a uisto que el camino de Tucuman y los yndios sircunvezinos e omaguacas an estado quietos y pacificos de manera que an podido entrar e salir libremente los que an querido tratar e contratar por el dicho camino y entrar para la gouernacion de Tucuman y saue este testigo que el dicho Joan Uelasquez Altamirano padre del dicho don Francisco Altamirano saco los yndios de Atacama // 


\section{[f. 27r]}

de paz con su yndustria costa y trabajo y a sido de mucha ynportangia para poderse caminar hasta Chile desde el Piru por tierra y que ansi mismo a oydo este testigo dezir y es publico e notorio que el dicho capitan Joan Uelasquez Altamirano padre del susso dicho se hallo en seruir a su magestad en todas las ocassiones que se ofrecieron desde que entro en este reyno hasta que murio y particularmente en la batalla de Chuquinga con el mariscal Alonsso de Aluarado y en la uilla de Potossi en la prision y muerte de Egas de Gusman persona que se auia aleado en la dicha uilla en desseruiçio de su magestad y en las demas cossas que en su tiempo se ofrecieron y por los dichos seruiçios que tiene dichos su magestad le hizo merced y el marques de Cañete le dio la encomienda de la mitad de los yndios de Atacama que el dicho Joan Uelasquez saco de paz e que por ser yndios velicossos y de guerra el dicho Joan Uelasquez Altamirano no quisso cobrar ni all pressente cobra el dicho don Francisco Altamirano mas de lo que ellos de su voluntad le quieren dar e que lo que se saca de los dichos yndios es principal- //

\section{[f. 27v]}

mente para pagar el signodo all sacerdote que los doctrina e por esta caussa e por auersse ocupado el dicho Joan Uelasquez Altamirano en las dichas ocassiones y no auer atendido a otra cossa mas que all seruiçio de su magestad sin tratar en cossas de su prouecho y grangerias auer tratado sus perssonas onrradamente con lustre y conforme a su calidad an quedado y estan muy pobres e neçessitados y el dicho don Francisco Altamirano tiene su cassa en esta dicha ciudad e sustenta en ella a su madre y quatro hermanas y doz hermanos a cuyo cargo esta el remedio dellos en quien cabra muy bien la merced que su magestad fuere seruido de hazerle all dicho don Francisco Altamirano no ansi en darle renta en yndios mejorandole en los que tiene como mandandole ocupar en oficios y cargos de justicia de que este testigo entiende dara buena quenta e de todo lo que se le encomendare y que esto que a dicho a declarado es la uerdad e lo que saue como persona que a estado y ressidido en esta dicha ciudad //

\section{[f. 28r]}

y prouincia a conoçido e tratado de hordinario a los dichos don Francisco Altamirano y a su padre del tiempo que dicho e declarado tiene a esta parte e lo firmo de su nombre e dixo ser de hedad de cinquenta años don Fernando de Çarate ante mi Joan de Lossa.

[al margen: capitan Barrasa]

El dicho capitan Francisco de Barrasa ressidente en esta dicha çiudad y corregidor de la prouincia de Omaguaca testigo susso dicho auiendo jurado en forma e siendo preguntado por el tenor de la peticion pressentada por el dicho capitan don Francisco Altamirano dixo que conoce all dicho don Francisco Altamirano de diez años a esta parte e anssi mesmo conocio a Joan Uelasquez Altamirano su padre del dicho tiempo a esta parte de uista y habla trato y comunicacion y all primero capitulo y los demas dixo lo siguiente:

Preguntado por el primero capitulo dixo que saue que los yndios de Omaguaca casauindos e Cochinoca e otros muchos en la prouincia de Tucuman y camino della se reuelaron contra la corona real //

\section{[f. 28v]}

de manera que ympedian el passo y comercio de aquella prouincia a este reyno e no se podia passar a ellos sino era con mucha gente y bien pertrechados de armas e lo demas que era nescessario y esto lo saue este testigo porque se hallo en aquella sazon en esta prouincia.

All segundo dixo que saue que los señores pressidente e oydores desta real audiencia a uisto el peligro e ynquietud que los dichos yndios tenian y el que resceuian las perssonas que pasauan yuan o uenian a la dicha prouincia de Tucuman e otras partes e para que estuuiesse quieto y pacifico e que se pudiesse tratar y contratar por el daño que de no hazer su magestad y particulares resceuian enbiaron all capitan Martin de Almendras vezino desde dicha ciudad por general con muchos soldados para apaciguar la guerra y aquellas prouincias por estar aliados y alçados los dichos yndios e para ponerlo en execucion y cumplimiento de lo que esta dicho en Ocloya los dichos yndios reuelados mataron all dicho general Martin de Almendras y veinte leguas en la prouncia de los lules mataron a Joan de Çiancas persona que auia ydo // 
a la dicha pacificacion en compañia y capitan del dicho Martin de Almendras y algunos de los dichos soldados se passaron a la prouincia de Tucuman porque no se atreuieron a boluer a estos reynos por tener los dichos yndios cercados y tomados los passos y esto lo saue este testigo porque a la dicha sazon se hallo en la frontera de Tarixa y conquista dellas.

E all tercero capitulo dixo este testigo que saue que despues de lo dicho fue a la jornada del ualle de Jujuy el capitan Pedro de Çarate con Crispoual Barua de Aluarado y Gaspar de Rojas y otros muchos soldados y a la poblacion del y estando poblados el dicho capitan Pedro de Çarate fue a pedir socorro al gouernador de la prouincia de Tucuman que era Goncalo de Abrego y quando boluio hallo despoblado el pueblo de San Francisco de Jujuy que estaba poblado e los dichos yndios mataron all dicho capitan Crispoual Barua y a Gaspar de Roxas y su hijo y esto es publico e notorio e lo saue este testigo //

\section{[f. 29v]}

por lo que tiene dicho.

$\mathrm{Y}$ all quarto capitulo dixo que saue que el dicho capitan Pedro de Çarate uisto lo susso dicho salio de la dicha prouincia con mucho riesgo de su persona e la demas gente que con el uenia por las razones que dichos y declarados tiene y estar los dichos yndios reuelados despues de lo qual saue e uio este testigo que el capitan Joan Uelasquez Altamirano padre del dicho don Francisco Altamirano fue por corregidor de la prouincia de Atacama el qual con su yndustria e yntelligencia procuro atraer de paz a los yndios del ualle de Omaguaca casauindos cochinocas e los demas yndios que estauan reuelados e reducirlos a la santa fee catolica y all seruiçio de su magestad como esta dicho e por medio de los caciques de Atacama de su encomienda y para que lo susso dicho tuuiesse mas efeto el dicho capitan Joan Uelasquez Altamirano embio all dicho don Francisco Altamirano su hijo a tratar de lo susso dicho y para que todo estuuiere quieto y pasifico del ualle de Omaguaca Casauindo //

\section{[f. 30r]}

en lo qual el dicho don Francisco Altamirano por ser la tierra reuelada y los yndios aleados se pospusso [sic] a mucho trauajo riesgo e peligro de la uida y mediante la yndustria cuydado e diligencia que el dicho don Francisco Altamirano pusso traxo de paz a don Diego Viltipoco y a sus yndios y a los de omaguaca que era capitan de toda aquella prouincia que estauan aleados y reuelados contra la corona real que fue de mucho seruicio de Dios nuestro señor y el de su magestad porque auian hecho muchas muertes ansi de hombres como de mugeres y estaua ympedido el passo de aquella tierra para esta prouincia y otras partes con lo qual cesso lo susso dicho y el dicho don Francisco Altamirano traxo a esta corte algunos de los caciques principales e uisto por los señores pressidente y oidores se les dio liçençia y perdon para que se boluieran a su tierra con lo qual quedo de paz la dicha prouincia y el dicho don Francisco Altamirano //

\section{[f. 30v]}

trauajo en ello con mucho cuydado e diligencia como leal uassallo de su magestad en lo qual el dicho don Francisco Altamirano y su padre de fuerca auian de gastar mucha hazienda en los dichos seruicios y poner de paz los dichos yndios en tierra tan aspera e peligrossa y que tenia en su compañia muchos soldados y amigos a quien sustentauan por que tenian necessidad de ualersse dellos y ansimismo fue de mucha consideracion auer traido los dichos yndios de paz porque despues aca se han descubierto minas oro plata y azogue que de fuerça an de ser de mucha conssideracion para su magestad y particulares por lo qual saue este testigo no se les a hecho all dicho don Francisco Altamirano merced ninguna el qual esta muy pobre e necessitado y cargado de madre y quatro hermanas e dos hermanos a quien sustenta e tiene en su cassa en esta dicha ciudad y el susso dicho se trata como hombre principal lustrosa-//

\section{[f. 31r]}

mente y que la merced que su magestad hizo all dicho Joan Uelasquez Altamirano padre del dicho don Francisco Altamirano en que subcedio el susso dicho que es la encomienda de yndios de Atacama es de muy poco prouecho y excessiuo trauajo porque es muchas leguas desta ciudad aspera y fragossa y que los dichos yndios no pagan mas de lo que quieren e por otro camino no se puede tratar con ellos y que pagado el sacerdote corregidor e otras cossas no le queda nada all dicho don Francisco Altamirano porque todo se gasta en pagar all dicho sacerdote que de ordinario esta en el dicho repartimiento para administrar y doctrinar a los dichos yndios y que 
en el tiempo que este testigo conocio all dicho Joan Uelasquez Altamirano padre del dicho don Francisco ni en que a conocido all dicho don Francisco no a uisto este testigo que los susso dichos ayan desseruido a su magestad en cossa alguna antes siruiendole con mucho //

\section{[f. 31v]}

cuydado e diligencia en las ocassiones que se an ofrescido como muy buenos y leales uasallos por lo qual y estan [sic] como all pressente esta el dicho don Francisco Altamirano tan pobre e necessitado y con madre hermanas y hermanos que los sustenta e tiene en su cassa es digno y merescedor de que su magestad le haga merced y ocuparle en oficios y cargos honrrosos de los quales les paresce al testigo dara muy buena quenta porque es hombre principal acudira a su obligacion y esta es la uerdad para el juramento que hizo en que se afirmo y ratifico e lo firmo de su nombre e que es de hedad de cinquenta y cinco años poco mas o menos fuele encargado el secreto prometiolo Francisco de Chaues Barassa ante mi Joan de Lossa.

\section{[al margen: Testigo Fustes Sanchez de Lara (sic)]}

El dicho Fustel Sanchez de Lada residente en esta ciudad el qual despues de auer jurado en forma prometio de dezir uerdad e siendo preguntado por el tenor de la peticion presentada por //

\section{[f. 32r]}

\section{el dicho Francisco Altamirano:}

Dixo que conoce all susso dicho de vissta habla trato e comunicacion y ansi mesmo conocio all capitan Joan Uelasquez Altamirano su padre e que lo que saue es que los yndios omaguacas calchaqui casavindo e los demas que estauan reuelados contra la corona real que es camino de Chile e de otras partes y que no se podia passar a la prouincia de Tucuman ni a la de Chile sino era con mucho riesgo y peligro de las uidas y haziendas tanto que cessaua el trato y comercio del dicho camino para lo qual era nescessario muchas perssonas e yr bien aderesçados de armas para poder andar por la dicha tierra e uisto por los señores presidente e oydores desta real audiencia mandaron all capitan Martin de Almendras fuese a poner remedio en pacificacion de aquella tierra y a escussar los daños peligros de muertes y otros desastres que subcedian por estar //

\section{[f. 32v]}

como estauan los dichos yndios alçados y reuelados y en compañia del dicho Martin de Almendras fueron otras muchas perssonas y entre ellas Joan de Siancas encomendero de los yndios omaguacas a los quales mataron los dichos yndios en los enquentros que con ellos tuuieron y otros de los dichos soldados se pasaron a Tucuman por el peligro en que se uieron despues de lo qual saue le uio este testigo que el capitan Pedro de Çarate fue a la jornada y poblacion del ualle de Jujuy y con el qual fueron el capitan Gaspar de Roxas y el capitan Crispoual Barua que tenian yndios encomendados en aquellas prouincias e otros muchos y estando poblados en el ualle de Salta auiendo ydo el dicho capitan Pedro de Çarate por socorro all gouernador de Tucuman en el ynterin los dichos yndios mataron a los susso dichos e otros muchos e uisto por el dicho capitan Pedro de Çarate se uino a esta prouincia con mucho //

\section{[f. 33r]}

riesgo de su uida por estar entre sus enemigos e que los dichos yndios matauan otras muchas perssonas como estauan aleados despues de lo qual fue proueydo por corregidor de la prouincia de Atacama ell capitan Joan Uelasquez Altamirano padre del dicho don Francisco Altamirano el qual saue este testigo procuro traer de paz a los dichos yndios $y$ reducirlos a nuestra santa fee y all seruicio de su magestad $y$ cuitar los peligros daños e muertes que subçedian del dicho leuantamiento con mucho cuydado e diligencia e que el dicho Joan Uelasquez Altamirano le dixo a este testigo que auia enuiado all dicho don Francisco su hijo a tratar de la dicha pacificasion all dicho ualle de Omaguaca con los dichos yndios el qual mediante su buena diligencia e cuidado saco de paz los dichos yndios que estauan algados en lo qual de fuerza auia de ponersse en mucho riesgo y peligro haziendo muchas costas de su hazienda en armas cauallos e otras //

\section{[f. 33v]}

cossas nescessarias que son menester en semejantes cassos con lo qual se escusso las dichas muertes y otros desastres que subcedian y el dia de oy estan de paz y ansimismo el dicho don Francisco Altamirano trajo a esta corte a algunos yndios principales de Casauindo segun oyo dezir y con esto quedo segura la dicha tierra y en pacificacion e que se les auia dado licencia para boluersse a sus tierras y en lo 
susso dicho el dicho don Francisco Altamirano saue este testigo siruio a su magestad con mucho cuydado e diligencia como becino y leal uasallo y le paresçe que el dicho su padre y el harian muchas costas y gastos en lo susso dicho y que no saue que su magestad les diesse ayuda de costa por ello y que de fuerça auian de tener los susso dichos otras costas y gastos ansi en perssonas que se les llegarian e ayudarian a la dich a pacificacion como soldados particulares y que con lo susso dicho quedo quieto y sosegado e lo estan los dichos yndios sin se auer tornado a alçar //

\section{[f. 34r]}

ni hazer los daños que tiene dicho e que no saue este testigo que por lo susso dicho se les aya hecho merced ninguna y el dicho don Francisco esta muy pobre e nescessitado e sustenta su madre y quatro hermanas donzellas e dos hermanos e tiene su cassa en esta dicha ciudad y que el repartimiento de yndios de que su magestad hizo merced all dicho Joan Uelasquez Altamirano padre del dicho don Francisco saue este testigo que es de poca conssideracion e los yndios muy pobres e la tierra aspera y fragossa y que no pagan mas de aquellos que ellos quieren dar por ser yndios muy pobres y que sacado el estipendio del sacerdote y otras cossas no queda all dicho don Francisco cossa que sea de conssideracion y que por los seruicios y ocassiones en que el dicho Joan Uelasquez Altamirano y el dicho su hijo an hecho a su magestad es digno merecedor de que su magestad le haga merced all dicho don Francisco Altamirano de ocuparse en cargos y corregimientos honrrossos conforme a la calidad de su perssona de los quales entiende //

\section{[f. 34v]}

este testigo dara buena quenta porque procede en todo como hombre lustrosso e trata su perssona honrradamente y ansimismo alguna encomienda de yndios que sea de mas conssideracion que la que tiene y quitandossela [sic] con augmento para que en lo susso dicho se pueda sustentar siendo su magestad seruiçio y acudir all remedio de su madre y hermanas y ansi mismo saue que el dicho Joan Uelasquez Altamirano se hallo en la prission de Joan de Santa Cruz e le trajo de Sococha a la uilla de Potossi por hombre uelicosso en que su magestad fue seruiçio del qual se hizo justicia por ser hombre uelicosso ynquieto y desasosegado [sic] con que se escusaron pesadumbres y ansi mismo saue este testigo que los susso dichos no an desseruiçio en cossa alguna a su magestad antes ocupadose siempre en su seruiçio como tiene dicho por lo qual e lo demas que tiene dicho sera bien empleada qualquiera merced que su magestad sea seruiçio hazer all dicho don Francisco Altamirano de encomendarle en algunos //

\section{[f. 35r]}

yndios que bacaren haziendo dexacion de los de Atacama porque como dicho tiene no son de aprouechamiento ninguno y ocupar su perssona en cargos y oficios honrrosos porque como dicho tiene el dicho su padre siruio a su magestad como muy bueno y leal uasallo e lo mesmo a hecho el dicho don Francisco Altamirano gastando sus haziendas en lo suso dicho que a sido caussa de auer quedado y estar el susso dicho tan pobre como lo esta y tener a su cargo y en su cassa sustentando a su madre quatro hermanas donzellas e dos hermanos y que esto que dicho e declarado tiene lo saue este testigo por que a mas de quarenta años que este testigo esta en esta prouincia e a uisto lo susso dicho como perssona que a tenido a su cargo oficios onrrosos en la milicia e otras ocupassiones siruiendo a su magestad en ellas y esta es la uerdad para el juramento que tiene hecho y en ello siendole leido se afirmo y ratifico e lo firmo de su nombre dijo ser de hedad de çinquenta y siete años fuele encargado el secreto prometiolo //

\section{[f. $35 \mathrm{v}$ ]}

Fustel Sanchez de Lada ante mi Joan de Lossa.

En la ciudad de La Plata ueinte y vn dias del mes de junio de mili e quinientos y setenta años ante los señores pressidente y oidores de la real audiencia y chancilleria que resside en esta ciudad estando haziendo audiencia publica por ante mi Tristan Sanchez escriuano de su magestad y de camara de la dicha real audiencia parescio presente Joan Uelasquez Altamirano vezino desta ciudad y pressento vna peticion e ciertas preguntas su tenor de lo qual es este que se sigue.

\section{[al margen: peticion]}

Muy poderosso señor Joan Uelasquez Altamirano vezino desta ciudad digo que yo e seruido a su magestad en estos reinos de veinte años a esta parte en todo lo que se a ofrescido e tengo nescessidad de hazer mi probança para la pressentar ante su real perssona y en el conssejo de las yndias o ante el 
señor vissorey para lo que toca a mi gratificacion e para otros efetos que me conuienen //

\section{[f. 36 r]}

pido y suplico a vuestra alteza mande que se resciuan los testigos que por mi parte se pressentaren sean exssaminados por las preguntas deste ynterrogatorio de que hago pressentacion y lo que dixeren e depusieren se me de en publica forma ynterponiendo a ello su autoridad y decreto judicial citando ante todas cossas para ello la parte de vuestro fiscal.

1. Primeramente si conocen a mi el dicho Joan Uelasquez Altamirano e si sauen que a veinte años que ressido en estos reinos del Piru.

2. Si sauen que al tiempo que Egas de Gusman se algo en la uilla ymperial de Potossi me trajeron presso los tiranos del assiento de Porco donde ressidia y llegado adonde el dicho Egas de Gusman estua y auiendome buelto mis armas despues que me las auian quitado fui uno de los que prendieron al dicho Egas de Gusman estando entre mucha gente de los suyos con mucho riesgo de mi perssona y le guarde hasta tanto que se hizo justicia del y de otros sus sequazes //

\section{[f. 36v]}

con que se acauo la dicha tirania digan lo que sauen e uieron acerca desto.

3. Y si sauen que despues que se concluyo la dicha tirania el mariscal Alonsso de Aluarado uino a ella e yo ressidi en la uilla de Potossi todo el tiempo que el dicho mariscal hizo el dicho castigo guardando y acompañando su perssorza e saliendo a prender a muchos de los delinquentes fuera del dicho asiento por su mandado e los traxe pressos como fue a Joan de Santa Cruz e a los que con el estauan licuando conmigo gente todo lo qual hize a mi costa y minssion sin darme socorro alguno para ello y gaste en el dicho tiempo mucha cantidad de pesos de oro.

4. Y si sauen que estando haziendo el dicho castigo el dicho mariscal uino nueua del alzamiento de Francisco Hernandez Giron en la ciudad del Cusco y como se auia apoderado con ella contra el seruiçio de su magestad e yo sali en acompañamiento del dicho mariscal con mis armas y cauallos y aderemos de guerra debajo del estandarte //

\section{[f. 37r]}

real e fue toda la dicha jornada que fue larga e muy costossa en que gaste mas de tres mili castellanos.

5. Y si sauen que me halle en la batalla que el dicho Francisco Hernandez dio contra el estandarte real en el ualle de Chuquinga donde el dicho mariscal fue desuaratado y alli me rouaron todo quanto tenia.

6. Y si sauen que auiendome escapado de la dicha, batalla fui por muchos despoblados a riesgo de mi perssona en busca del campo de su magestad y me junte con el capitan Gomez de Solis debajo del estandarte real y me halle en su acompañamiento all tiempo que fue desbaratado por los tiranos en la ciudad de Arequipa despues de lo qual estuue en el Desaguadero con la guarnicion e gente de guerra que alli estuuo guardando aquel passo hasta que Francisco Hernandez Giron fue desbaratado en la batalla de Pucara y estos reynos reducidos all seruicio de su magestad.

7. Y si sauen que despues de todo lo susso dicho auiendo estado los yndios de Atacama //

[f. 37v]

veinte e dos años de guerra y aleados e negado la ouediencia de su magestad e muerto muchos españoles estado ataxado el camino de Chile por la dicha razon con mi perssona e amigos y dadiuas que les di en que gaste mas de seis mili pessos los traxe de paz e hize poblar en el camino real como los demas e an estado paçificos y quietos hasta oy.

8. Y si sauen que por el dicho seruicio el marques de Cañete vissorey que fue destos reynos por el dicho seruicio me encomendo los dichos yndios e para podellos sustentar e tener de paz me dio dos mili pessos de salario con titulo de corregidor con el qual y con el dicho salario lo estuue año y medio gastando yo mucho mas de mi hazienda en sustentarlos y amansarlos como a gente recien reducida. 
9. Y si sauen que llegado el conde de Nieua y comissarios me quitaron el dicho cargo y salario e del hizieron corregimiento ordinario y ansi se a proueido hasta agora en otras perssonas.

10. Y si sauen que por auersse hecho la dicha //

[f. 38r]

la dicho [sic] mundanga y malos tratamientos que a los dichos yndios se an hecho haziendoles labrar ropa an estado muchas vezes en terminos de se alear y en efeto hecho si con mi yndustria y dadiuas e buenos tratamientos que les e hecho no se ouiera estoruado porque todos sus comarcanos estan de guerra y alçados y muerto mas de çien hombres de ocho años a esta parte.

11. Y si sauen que en todo el dicho tiempo que a que los tengo en encomienda no les e licuado mas tributo ni lleuo mas de lo que ellos quieren dar de su voluntad y por la dicha razon de dos mili y ducientos pessos en que estan tassados en cada un año me deuen all pressente mas de seis mili pessos los quales no pido ni cobro por no apretarlos ni dessabrirlos.

12. Y si sauen que siempre e tenido en los dichos yndios sacerdote que los doctrine pagandole de mi hazienda mucha parte del salario e por sustentarlos e ydo muchas vezes en persona a su tierra con gran peligro y rriesgo de mi //

\section{[f. 38v]}

perssona anssi por los despoblados e grandes nieues como de los mismos yndios por no estar aun seguros ni bien asentados.

13. Y si sauen que soy hombre quieto y pacifico y assentado temerosso de Dios de buena uida y fama y despues que tengo los dichos yndios se an bautizado e cassado gran cantidad y que en la uissita general que se hizo por mandado del obispo ninguno se hallo mas bien doctrinados y que los dichos yndios vienen a esta ciudad y a Potossi a sus contratassiones y ressiden en ella caciques y principales del dicho rrepartimiento.

14. Y si sauen que despues que tengo los dichos yndios e sustentado cassa y uezindad en esta ciudad de La Plata con armas y cauallos y casa poblada e salido muchas vezes della a jornadas que el señor pressidentte a hecho contra los chiriguanaes que an estado de guerra y en otras que me an encargado por ser hombre de confiança todo a mi costa sin darme socorro ninguno para ello y a otras partes e lugares donde el audiencia [sic] real me a mandado que vaya e ayudado //

a todo lo demas las cargas de la republica.

15. Y si sauen que soy cassado con perssona principal e de calidad e tengo cinco hijos y que estoi muy pobre e no me puedo sustentar e que cabria en mi qualquiera merced que su magestad fuesse seruido de hazerme ansi por mis meritos e seruicios como por ser perssona que segun la costumbre que e tenido hasta aqui lo gastare siruiendo a su magestad y lo podre hazer con la possibilidad que se requiere.

16. Y si sauen que todo lo susso dicho es publico y notorio e publica uoz y fama Joan Uelasquez Altamirano.

E uisto por los dichos señores mandaron que se tome la ymformacion como lo pide con çitaçion del fiscal Tristan Sanchez.

[al margen: citacion a el fiscal]

En este dicho dia mes y año dicho yo el pressente escriuano de camara notifique el auto de susso contenido al liçenciado Rauanal fiscal de su magestad y le cite e aperceui para que se hallasse pressente all uer presentar //

\section{[f. 39v]}

jurar e conoscer los testigos que en la dich a prouança se pressentaren por el dicho Joan Uelasquez Altamirano que lo oyo siendo testigos Alonsso Aluarez e Pedro Bela Tristan Sanchez.

[al margen: testigo]

E despues de lo susso dicho en la dicha ciudad de La Plata a ueinte e dos dias del mes de junio del dicho año de mill y quinientos y setenta años en pressencia del muy illustre señor liçençiado Pedro Ramirez de Quiñones pressidente de la dicha real audiencia el dicho Joan Uelasquez Altamirano pressento por testigo para la dicha ymformacion all liçenciado 
Polo Ondegardo vezino desta dicha ciudad del qual fue tomado e resceuido juramento sobre una señal de cruz que hizo con los dedos de sus manos e por las palabras de los santos euangelios que diria la verdad de lo que supiesse e le fuesse preguntado en este casso que era pressentado por testigo y a la fuerça y conclusion del dicho juramento dixo si juro e amen e siendo //

\section{[f. 40r]}

preguntado por las preguntas del dicho ynterrogatorio dixo lo siguiente:

1. A la primera pregunta dixo que conoce all dicho Joan Velasquez Altamirano de los veynte años que la pregunta dize poco mas o menos en este reyno del Piru.

\section{[al margen: Generales]}

Preguntado por las preguntas generales dixo ques de hedad de quarenta años poco mas o menos y que no le toca las generales. [...]

\section{[f. 41v]}

7. A la septima pregunta dixo que este testigo saue que los yndios de Atacama auia muchos años que estauan rreuelados y fuera de la ovediencia de su magestad e que no se podia passar por alli para la prouincia de Chile sino era gente junta porque en uezes auian muerto cantidad de españoles y gouernando este testigo esta prouincia tenia mucha noticia desto por ser de su jurisdicion e al tiempo que la pregunta dize saue este testigo que el dicho Joan Uelasquez tomo a su cargo la pacificacion dellos y con la amistad e comunicacion que tomo con la gente comarcana que estaua de paz como los caciques chichas e otros empego a tratar a los dichos yndios de Atacama yendo muchas vezes a ello por despoblados y lugares rremotos e con muchas dadiuas que les dio e diligencias que hizo los vino //

\section{[f. 42r]}

a traer de paz e que muchas vezes creyo este testigo que lo auian de matar en los dichos tratos y ansi lo tenia por cierto hasta que los dichos yndios uinieron a esta ciudad de paz y despues aca siempre a tenido poblado el camino rreal e an tenido corregidor y clerigo que los doctrina y el camino de Chile a estado y esta seguro en lo qual le paresce a este testigo que no pudo dexar de ser mucho lo que el dicho Joan Velasquez gasto porque no se podia hazer sin muchas dadiuas ansi a los caciques como a los que yuan en compañia del dicho Joan Uelasquez Alta-mirano españoles e yndios se auia de gastar mucho con ellos porque duro la dicha pacificacion tiempo largo e ansi fue publico y notorio entonces e lo es agora para lo qual de nescessidad fue nescesario gran yndustria trabajo e dineros porque sin esto no podia auer auido efeto y esto saue desta pregunta y responde a ella.

8. A la otaua pregunta dixo que este testigo saue que por la dicha razon fueron encomendados los dichos yndios en el dicho Joan Uelasquez en las dichas prouincias //

\section{[f. 42v]}

de Atacama e que rresidio en ellos cierto tiempo que se rremite a la çedula de encomienda e titulo de corregidor que tubo e tiene y en aquel tiempo el dicho Joan Uelasquez avio la gente que fue a Chile con don Garçia de Mendoga que fue por gouernador a Chile y que en lo uno y en lo otro el dicho Joan Uelasquez siruio a dios y a su magestad porque nunca este testigo creyo que se pudieran pacificar sin muchas muertes y el dicho Joan Uelasquez sin guerra ni ningun aluoroto los pacifico y los dichos yndios se reduxeron muy bien e anssi lo estan hasta oy y esto responde a esta pregunta.

9. A la nouena pregunta dixo que este testigo saue que el corregimiento ordinario es de la prouincia de Atacama y este testigo lo a visto en poder de diferentes perssonas que licuan su salario e que saue que el dicho Joan Uelasquez no le a tenido dende el dicho tiempo y que quando le tubo no podia dexar de gastar lo que le dauan y algo mas por ser rrecien rreduzidos los yndios de aquella proumda y esto saue desta pregunta e rresponde a ella. //

10. A la dezima pregunta dixo que este testigo saue que todos los comarcanos de Atacama estan aleados y de guerra como son los yndios de Calchaqui e apatamas e omaguacas que este testigo esta espantado como an guardado la paz tanto tiempo 
e que tiene por cierto que deue auer sido por la industria del dicho Joan Uelasquez porque poca ocassion an menester los dichos yndios para algarsse y reuelarsse por ser como son uelicossos y esto saue desta pregunta y responde a ella.

12. A las doze preguntas dixo que este testigo a uisto yr a el dicho Joan Uelasquez algunas vezes a las dichas prouincias de Atacama cuyo camino es peligrosso y trabajoso y por las razones contenidas en la pregunta y este testigo saue que a residido en la dich a prouincia el padre Justiniano muchos años con salario doctrinando los dichos yndios e lo demas contenido en la pregunta no lo saue.

13. A las treze preguntas dixo que este testigo tiene al dicho Joan Velasquez por tal perssona como la pregunta dize e por //

\section{[f. 43v]}

tal tiene entendido que le tienen todos porque sus obras e buena uida no dan lugar a otra cossa y este testigo no a oydo lo contrario y que los dichos caciques e yndios de Atacama a lo que este testigo entiende estan quietos e pacificos y que como tales uienen a sus contrataciones a esta prouincia y que esto saue desta pregunta e responde a ella.

14. A la catorze pregunta dixo que este testigo saue la pregunta como en ella se contiene y porque a uisto hazer all dicho Joan Velasquez vezindad en esta ciudad e tener cassa poblada e licuar las demas cargas de la republica como los demas vezinos y tener sus armas e todo lo demas nescesano muy a punto e demas desto le a uisto salir con el señor pressidente diferentes vezes a partes que a sido nescessano muy bien aderescado y entender en cossas e negocios lo qual a hecho con mucha diligencia e cuidado y ansi es tenido por hombre de mucha confianza en el seruiçio de su magestad y a este testigo //

\section{[f. 44r]}

le paresce que qualquiera cossa de ymportancia se le podria encargar muy bien e que dara muy buena quenta dello como siempre lo a hecho y esto saue desta pregunta y responde a ella. [...]

\section{[f. 44v]}

lo que dicho tiene lo qual es la uerdad y publico $\mathrm{y}$ notorio para el juramento que tiene fecho y firmolo de su nombre el liçenciado Polo ante mi Tristan Sanchez.

[al margen: testigo]

E despues de lo susso dicho en la dicha ciudad de La Plata en el dicho dia mes y año dicho el dicho Joan Uelasquez Altamirano presento por testigo para la dicha ynformaçion a Pedro Nuñez de Prado estante en esta ciudad del qual fue tomado e rresceuido juramento sobre una señal de cruz e por las palabras de los santos euangelios segun de suso e a la fuerça y conclucion del dicho juramento dixo si juro y amen e siendo preguntado por las preguntas del dicho ynterrogatorio dixo lo siguiente:

1. A la primera pregunta dixo que conoce all dicho Joan Uelasquez Altamirano en estos reinos del Piru podra auer diez y ocho años.

[al margen: generales]

Preguntado por las generales dixo que es de hedad de mas de quarenta años e que no es pariente de ninguna de las partes ni le enpece ninguna de las generales // [...]

\section{[f. 46v]}

7. A la septima pregunta dixo que lo contenido en la pregunta lo a oydo dezir este testigo por cosa publica a algunas perssonas de cuyos nombres no se acuerda.

8. A la otaua pregunta dixo que es cossa publica en esta prouincia lo que la pregunta dize e anssi lo oyo dezir este testigo que se remite a la encomienda de los dichos yndios e titulo de corre gimiento por donde constara.

9. A la nouena pregunta dixo que saue que a auido corregidores en la prouincia de Atacama despues que el conde de Nieua vino a este reyno y este testigo a uisto algunos dellos en esta prouincia e que es cossa publica y notoria que agora resside alli por corregidor don Francisco Lobato e que esto sabe desta pregunta.

16. A la ultima pregunta dixo que dize // 
10. A las diez preguntas dixo que saue por cossa publica e notoria que los yndios comarcanos a Atacama como son II

\section{[f.47r]}

Calchaqui y omaguacas de quatro años a esta parte an muerto algunos españoles y que tiene por cierto que si los yndios de Atacama no se an rreuelado que a sido parte el dicho Joan Uelasquez por los buenos tratamientos que les a hecho e hizo quando alli fue corregidor que esto saue desta pregunta.

11. A las onze preguntas dixo que dize lo que dicho tiene en las preguntas antes desta a que se refiere y ansi mismo se refiere a la dicha tassa y que a oydo dezir al dicho Joan Uelasquez que le deuen muchos dineros de la tassa.

12. A las doze preguntas dixo que este testigo a oydo dezir por cossa publica que el dicho Joan Velasquez a tenido en el dicho repartimiento de Atacama dotrina suficiente de vn clerigo que a dotrinado los dichos yndios el qual a visto este testigo algunas veces en esta ciudad y dezia que uenia del dicho repartimiento y le a uisto tornar a boluer aunque de seis messes a esta parte poco mas o menos no a buelto all dicho repartimiento e que esto saue desta pregunta.

13. A las treze preguntas dixo que este testigo saue que el dicho Joan Uelasquez es hombre //

\section{[f. $47 \mathrm{v}$ ]}

quieto $y$ pacifico temeroso de dios y de su conciencia $y$ de buena uida $y$ fama por lo que a tratado $y$ comunicado $y$ que auiendo tenido en el dicho repartimiento sacerdote como dicho tiene tanto tiempo no puede dexar de auer bautizado muchos yndios y casado otros e que siempre a oydo dezir que el dicho Joan Velasquez trata a los dichos yndios muy bien e que los caciques e yndios que a visto en esta ciudad siruen all dicho Joan Uelasquez de buena gana y que les haze muy buenos tratamientos y que esto saue desta pregunta.

14. A las catorze preguntas dixo que lo que della saue es que este testigo a visto que el dicho Joan Uelasquez se a tratado en esta ciudad muy onrradamente y tiene su cassa en ella y siempre le a visto tener sus armas y cauallos e biue onrrosamente con su muger e hijos y este testigo le a uisto salir desta ciudad con el señor pressidente a algunas jornadas de yndios chiriguanaes que auian salido a los terminos desta ciudad con sus armas y cauallos y este testigo le a visto //

[f. 48r]

le a visto [sic] ser corregidor desta ciudad e ussar muy bien su oficio por que es tal persona que cabe en el qualquier cargo y esto saue desta pregunta. [...] y que esto que dicho tiene es lo que saue es la uerdad para el juramento que fecho tiene e firmolo de su nombre Pedro Nuñez de Prado ante mi Tristan Sanchez.

[al margen: testigo el capitan Martin Monje]

E despues de lo susso dicho en la dicha ciudad de La Plata veynte e ocho dias del mes //

[f. 48v]

de junio del dicho año el dicho Joan Velasquez Altamirano pressento por testigo para la dicha ymformacion all capitan Martin Monje vezino desta ciudad del qual fue tomado y resceuido juramento en forma de derecho sobre una señal de cruz e por las palabras de los santos euangelios que dira la uerdad de lo que supiere y le fuere preguntado y a la fuerça del dicho juramento dixo si juro y amen e siendo preguntado por las preguntas del dicho ynterrogatorio dixo lo siguiente:

1. A la primera pregunta dixo que conoce all dicho Joan Uelasquez Altamirano del tiempo contenido en la pregunta poco mas o menos en este reyno del Peru.

[al margen: generales]

Preguntado por las preguntas generales dixo que es de hedad de mas de quarenta y ocho años e que no le tocan las generales de la ley. [...]

[f. 51r]

7. A la septima pregunta dixo que despues de se auer concluido la batalla de Pucara y allanada la dicha tirania del dicho Francisco Hernandez Giron e quieto pacifico este reino el dicho Joan 
Velasquez Altamirano por mas seruir a su magestad fue a la prouincia de Atacama juntamente con otros amigos suyos con sus armas y cauallos e a su costa e minssion y con muchos gastos y costas fue a la prouincia de Atacama y con buenos medios e yndustria los traxo de paz con halagos y dadiuas de muchas presseas y ropas que dio a los caciques e principales de los dichos yndios de Atacama y ansi el dia de oy estan los dichos yndios quietos y pacificos y antes desto estauan reuelados y matauan españoles como la pregunta lo dize en lo qual el dicho Joan Uelasquez siruio mucho a Dios nuestro señor y a su magestad lo qual saue este testigo //

\section{[f. 51v]}

porque fue con el a la dicha jornada e lo uio ser y passar ansi.

8. A la otaua pregunta dixo que este testigo saue que por comission del dicho marques de Cañete el dicho Joan Velasquez Altamirano ressidio por corregidor en el dicho ualle de Atacama en sustentacion de los dichos yndios y que en esto y en lo de la encomienda del dicho repartimiento se remite a la dicha encomienda y esto responde a esta pregunta.

9. A la nouena pregunta dixo que despues que uinieron a este reino el conde de Nieua e comissarios siempre este testigo a uisto que se a proveido el dicho corregimiento de Atacama en perssonas particulares e nunca mas a uisto all dicho Joan Velasquez Altamirano ser corregidor, de la dicha prouincia como de antes lo solia ser e que por esta razon este testigo entiende y esta claro lo an hecho corregimiento ordinario y esto responde a esta pregunta.

10. A la dezima pregunta dixo que este testigo saue e a uisto que el dicho Joan Uelasquez Altamirano a hecho e haze muy buen tratamiento a los caciques e yndios del /

\section{[f. $52 \mathrm{r}]$}

dicho repartimiento de Atacama por lo qual los dichos yndios casso que esten poblados en comarca de gente de guerra estan quietos y paçificos poblados en el camino real que va a las prouincias de Chile y en su comarca ay muchos yndios alçados e reuelados fuera de la obediencia real de su magestad e que esto responde a ella e lo demas no lo saue.

12. A las doze preguntas dixo que este testigo saue que en la dicha prouincia de Atacama a ressidido ordinariamente sacerdote doctrinando los yndios del dicho repartimiento e que desde esta ciudad a la dicha prouincia ay largo camino e peligrosso por las razones que dize la pregunta y este testigo saue que el dicho Joan Uelasquez a ydo a la dicha prouincia muchas vezes despues que los a tenido en encomienda e que por ser el camino tan largo e trabaxosso de nieues y despoblados de arenales no a podido dexar de pasar gran riesgo de su uida y esto responde a esta pregunta.

13. A las treze preguntas dixo que este testigo tiene all dicho Joan Uelasquez Altamirano por tal perssona e de tan buena uida y fama //

\section{[f. 52v]}

como la pregunta dize e que a uiuido y biue noblemente e que los yndios del dicho repartimiento estan bien doctrinados y pasificos e bienen a esta prouincia y andan en sus contrataciones e a uisto en esta ciudad caciques principales e yndios del dicho repartimiento como la pregunta lo dize y esto saue desta pregunta e responde a ella.

14. A las catorze preguntas dixo que este testigo saue e a uisto que despues que el dicho Joan Velasquez Altamirano tiene en encomienda los dichos yndios de Atacama siempre a sustentado cassa e familia y armas e cauallos como la pregunta lo dize y que en las cossas que se an ofrescido tocantes all seruicio de su magestad a sido de los delanteros y como a hombre tan aparejado y zelosso del seruiçio de su magestad por el señor pressidente y real audiencia se le an encargado jornadas contra los chiriguanaes e siempre a ydo a ellas a su costa e minsion sin auer resceuido paga ni socorro alguno alguno para ello y esto responde a esta pregunta $[\ldots]$

[f. 53r]

16. A la diez e seis preguntas dixo que dize lo que dicho tiene lo qual es la uerdad e publico y notorio a este testigo para el juramento que tiene fecho y firmolo de su nombre Martin Monxe ante mi Tristan Sanchez. 
[al margen: testigo]

E despues de lo susso dicho en la dicha ciudad de La Plata a primero dia del mes de jullio del dicho año de mil y quinientos y setenta años el dicho Joan Uelasquez Altamirano pressento por testigo para la dicha ymformacion a Crispoual de Truxillo vezino desta ciudad del qual fue tomado e resceuido juramento en forma de derecho sobre una señal de cruz segun de los de susso so cargo del qual prometio de dezir uerdad y siendo preguntado //

\section{[f. 53v]}

por el tenor de las preguntas del dicho ynterrogatorio para que fue presentado dixo lo siguiente:

1. A la primera pregunta dixo que conoce all dicho Joan Uelasquez Altamirano de diez e ocho años a esta parte poco mas o menos en este rey no del Peru.

\section{[al margen: generales]}

Fuele preguntado por las preguntas generales de la ley dixo que es de hedad de mas de cinquenta e cinco años que no le tocan las generales. [...]

\section{[f. 56v]}

7. A la septima pregunta dixo que acauada la batalla de Pucara y quieto y pacifico este reyno el dicho Joan Velasquez Altamirano juntamente con otros amigos suyos bien aderesçados de armas y cauallos fue a la prouincias [sic] de Atacama y con su industria e buenos medios que para ello tubo //

\section{[f. 57r]}

trajo de paz a los yndios del dicho repartimiento y prouincia que estauan de guerra y tenian negada la obediencia de su magestad que matauan muchos españoles que yuan a las prouincias de Chile como la pregunta lo dize en cuya pacificaçion hizo el dicho Joan Velasquez gran seruicio a Dios nuestro señor y a su magestad e que pues atraxo a los dichos yndios de paz sin aluoroto ni guerra alguna creele y tiene por cierto este testigo que allende de su buena yndustria e buen medio no dexaria de dalles algunas dadiuas de ropas y otras cossas y que en lo uno y en lo otro no pudo dexar de gastar cantidad de pesos de oro porque nunca a uisto ni oydo dezir que para este efeto y jornada se le diesse de parte de su magestad socorro ni ayuda de costa alguna y esto saue desta pregunta e responde a ella.

8. A la otaua dixo que este testigo saue que el dicho marques de Cañete encomendo los dichos yndios de Atacama en el dicho Joan Uelasquez el qual despues //

\section{[f. 57v]}

que se los encomendo los a tenido e poseido haziendoles muy buenos tratamientos asistiendo en la dicha prouincia entre los dichos yndios por corregidor el tiempo que la pregunta dize asegurando aquel camino y que se remite a la cedula encomienda y titulo de corregimiento que la pregunta dize.

9. A la nouena pregunta dixo que despues que uinieron a este reyno el conde de Nieua y comissa-rios quitaron al dicho Joan Uelasquez el dicho corregimiento de Atacama e lo an proueido a perssonas particulares y esto responde a esta pregunta.

12. A las doze preguntas dixo que este testigo saue que siempre el dicho Joan Uelasquez Altamirano a hecho muy buen tratamiento a los yndios del dicho repartimiento de Atacama procurando su conuerssion y buena doctrina sobre lleuandolos en todo e que a ressidido en el dicho repartimiento sacerdote con salarios y que el dicho Joan Uelasquez a ydo muchaz vezes a la dicha prouincia a vessitar los dichos yndios cuyo camino //

[f. 58r]

es largo y trauajosso y peligrosso por las razones contenidas en la pregunta que es muy notorio y que esto saue desta pregunta e responde a ella.

13. A las treze preguntas dixo que este testigo tiene all dicho Joan Uelasquez Altamirano por buen cristiano temerosso de Dios y de su conciencia quieto y pacifico de buena vida y fama y por tal como la pregunta lo dize porque en sus obras trato y comunicacion lo a dado y da ansi a entender e que siempre a tenido sacerdote en la doctrina del dicho repartimiento que esta claro que a cabo de tantos años se abran bautizado y caussado [sic] 
muchos dellos y que los dichos yndios tienen sus tratos en esta prouincia y van y vienen y ressiden algunos dellos en ella e todos ellos estan de paz debajo de la ouediencia real de su magestad y esto responde a esta pregunta.

14. A las catorze preguntas dixo que este testigo saue e a uisto que el dicho Joan Uelasquez despues que se le encomendaron los //

\section{[f. 58v]}

yndios del dicho repartimiento de Atacama a tenido e tiene cassa poblada sustentando armas e cauallos como bueno y leal uasallo de su magestad $y$ a salido a algunas jornadas que se an ofrescido en acompañamiento del señor pressidente desta real audiencia contra los chiriguanaes y siempre con gran presteza e voluntad como hombre aparejado para las cossas tocantes al seruicio de su magestad e que no saue que se le aya dado socorro ni ayuda de costa para las dichas jornadas y esto saue desta pregunta e responde a ella. [...]

16. A las diez e seis preguntas dixo que dize lo que dicho tiene lo qual es lo que saue y la uerdad e publico e notorio e este testigo //

[f. 59r]

para el juramento que fecho tiene e firmolo de su nombre Cristoual de Truxillo ante mi Tristan Sanchez.

[al margen: testigo Gorualan de Robles]

E despues de lo susso dicho en la dicha ciudad de La Plata en el dicho dia mes y año dicho el dicho Joan Uelasquez Altamirano presento por testigo para la dicha ymformacion a el licenciado Gorualan de Robles abogado en la dicha real audiencia del qual fue tomado e resceuido juramento en forma de derecho sobre vna señal de cruz segun de susso e auiendo jurado e siendo preguntado por las preguntas del dicho ynterrogatorio dixo e declaro lo siguiente:

1. A la primera pregunta dixo que conoce all dicho Joan Uelasquez Altamirano desde antes del alçamiento de don Sebastian de Castilla. [al margen: generales]

Fue preguntado por las preguntas generales de la ley dixo que es de hedad de mas de quarenta e cinco años. [...]

[f. 61v]

7. A la septima pregunta dixo que este testigo saue que el dicho Joan Uelasquez Altamirano pusso gran solicitud e diligencia en traer de paz a los dichos yndios de Atacama mediante lo qual es publico y notorio auellos apaciguado y auer uenido de paz y seruidumbre y estar e ressidir muchos dellos en esta prouinçia siendo como eran y son yndios uelicossos e que es cossa publica e por tal este testigo lo a oydo dezir que el dicho Joan Uelasquez a dado muchas dadiuas a los dichos yndios e a gastado con ellos pero la cantidad cierta este testigo //

[f. 62r]

no lo saue y esto responde a esta pregunta.

8. A la otaua pregunta dixo queste testigo se remite a la cedula de encomienda que de los dichos yndios tiene y all titulo de corregidor que la pregunta dize y esto responde a esta pregunta.

14. A las catorze preguntas dixo que saue la pregunta segun e como en ella se declara por que lo a uisto ser e passar ansi como en ella se declara por auersse hallado a todo presente y esto responde a ella. [...]

16. A las diez e seis preguntas dixo que lo que dicho tiene es lo que saue e la uerdad y publico e notorio para el juramento que tiene fecho y firmolo de su nombre el liçenciado Gorualan de Robles ante mi Tristan Sanchez.

[f. 62v]

[al margen: testigo]

E despues de lo susso dicho en la dicha ciudad de La Plata quinze dias del dicho mes de julio del dicho año el dicho Joan Uelasquez Altamirano para la dicha ymformacion pressento por testigo a Toriuio de Alearas del qual fue tomado y resceuido juramento en forma de derecho sobre una señal de cruz e por las palabras de los santos euangelios que dira uerdad de lo que supiesse 
e le fuesse preguntado en este casso que era pressentado //

\section{[f. 63r]}

por testigo y a la fuerça del dicho juramento dixo si juro y amen e siendo preguntado por las preguntas del dicho ynterrogatorio dixo lo siguiente:

1. A la primera pregunta dixo que conoce all dicho Joan Velasquez Altamirano de quinze años a esta parte poco mas o menos en este rey no del Piru.

\section{[al margen: generales]}

Preguntado por las generales de la ley dixo que es de hedad de cinquenta años poco mas o menos e que no le tocan las generales e que Dios ayude a la uerdad. [...]

\section{[f. 64r]}

7. A la septima pregunta dixo que lo que della saue es que despues de la pacificacion y allanamiento de la tirania del dicho Francisco Hernandez Giron y sus aliados el dicho Joan Velasquez Altamirano por mas seruir a su magestad fue a las prouincias de Atacama que los //

\section{[f. 64v]}

yndios de la dicha prouincia en aquella sazon estauan alçados y de guerra e tenian negada la obediencia a su magestad e ympedian el uiaje a los españoles que yuan e uenian desta prouincia a las de Chile e matauan muchos dellos e que el dicho Joan Uelasquez con buenos medios y manos e yndustria que para ello tuuo con los caciques e yndios de la dicha prouinçia los traxo de paz e que fue cossa publica entre muchas perssonas en aquella sazon como a los dichos caciquez les daua muchas dadivas de ropas de seda y otras preseas e que los dichos caciques e yndios del dicho tiempo a esta parte siempre an estado quietos y estan quietos y pacificos debajo de la ouediencia real e que aquella jornada se hizo por el dicho Joan Velasquez e otros amigos suyos en la qual no pudo dexar de gastar cantidad de pessos de oro en los adereços de su perssona y amigos y esto responde a esta pregunta porque le uio yr a la dicha jornada // y aderesçarsse para ella.

8. A la otaua pregunta dixo que despues de auer traido de paz ell dicho Joan Uelasquez Altamirano los yndios de la dicha prouincia de Atacama estubo en ella con titulo de corregidor por cierto tiempo donde anparaua los dichos yndios y los regalaua e los tenia en doctrina y pulicia y que es cossa publica que el dicho marques de Cañete vissorey que fue destos reynos le encomendo la mitad del repartimiento de los dichos yndios de Atacama y los possee all pressente y que se remite a los titulos ycedulas que dello se [ilegible] paresçera lo que la pregunta dize y esto responde.

9. A la nouena pregunta dixo que despues que uinieron a este reyno el conde de Nieua y comissarios a uisto $\mathrm{yr}$ perssonas particulares por corregidores a las dichas prouincias de Atacama por lo qual se entiende lo an hecho corregimiento hordinario como la pregunta lo dize y esto responde a ella.

10. A la dezima pregunta dixo que los dichos yndios de Atacama tienen por comarcanos //

\section{[f. $65 \mathrm{v}]$}

muchos yndios de guerra y muy velicosos e que pues los dichos yndios an sustentado la paz hasta el dia de oy esta claro que a sido mediante el buen tratamiento e yndustria del dicho Joan Uelasquez Altamirano y dello es cosa publica e notoria y esto responde a esta pregunta.

11. A la onze preguntas dixo que no la saue mas de que dize lo que dicho tiene en las preguntas antes desta a que se refiere.

12. A las doze preguntas dixo queste testigo saue la pregunta como en ella se contiene porque despues que el dicho Joan Velasquez Altamirano tiene en encomienda los dichos yndios siempre a tenido con ellos sacerdotes que an entendido en su dotrina y el dicho Joan Velasquez a ydo a uissitarlos muchas vezes personalmente e que en el camino no a podido de auer passado gran riesgo y trabajo de su perssona y uida por los grandes despoblados de nieues y arenales que ay e por las demas razones que la pregunta dize que es como en ella se declara y esto responde a esta pregunta // 
13. A las treze preguntas dixo que este testigo saue la pregunta como en ella se contiene porque este testigo a tratado e comunicado all dicho Joan Uelasquez en esta prouincia despues que a que le conoce y le tiene por tal perssona como la pregunta lo dize y a uissto uissitarsse los dichos yndios por el juez ecleciastico en cuya vissita este testigo saue e uio que se hallo ser los dichos yndios muy bien doctrinados y que todo lo demas que la pregunta dize lo a uisto ser y passar ansi como en ella se declara y esto saue desta pregunta.

14. A la catorze preguntas dixo que saue la pregunta como en ella se contiene porque siempre este testigo le a uisto tener cassa poblada con armas y cauallos y le a uisto yr a las jornadas que la pregunta dize sin dar el socorro ni ayuda de costa lo qual saue este testigo por lo auer visto ser y pasar ansi como la pregunta lo dize. [...]

\section{[f. 66v]}

16. A la diez y seis preguntas dixo que lo que dicho tiene es lo que saue e publico y notorio para el juramento que fecho tiene y firmolo de su nombre Toriuio de Alearas Tristan Sanchez.

[al margen: testigo Sancho de Figueroa]

E despues de lo susso dicho en la dicha ciudad de La Plata a diez e siete diaz del mes de jullio de mill e quinientos y setenta años el dicho Joan Uelasquez Altamirano pressento por testigo para la dicha ymformacion a Sancho de Figueroa estante en esta corte del qual fue tomado e resceuido juramento //

\section{[f. 67r]}

en forma de derecho segun de susso e auiendojurado dixo si juro y amen e siendo preguntado por las preguntas para en que fue pressentado dixo lo siguiente:

1. A la primera pregunta dixo que conoce all dicho Joan Uelasquez Altamirano de mas de quinze años a esta parte en este reino del Peru. [al margen: generales]

Preguntado por las preguntas generales de la ley dixo que es de hedad de treinta años e que no le tocan las generales.

7. A la septima pregunta dixo que este testigo saue que los yndios de Atacama a la sazon que la pregunta dize estauan alçados y de guerra e como tales matauan muchos españoles que passauan por su tierra como fue a la gente que entrauan en las prouincias de Chile y Tucuman con Joan Nuñez de Prado y otros capitanes y el dicho Joan Velasquez con su buena yndustria dadiuas y regalos que hizo a los dichos caciques e yndios los traxo de paz lleuando como lleuo consigo en su acompañamiento muchos amigos suyos a su costa e minsion y despues de los auer traydo a la paz e teniendolos quietos lleuo a la dicha prouincia vn sacerdote para que los dotrinasse y enseñase las cossas de la santa fee catholica y que all tiempo y sazon que don Garcia iba //

\section{[f. 67v]}

gouernador a la prouincia de Chile los yndios de la dicha prouincia y el caçique e señor principal de los dichos yndios que se dezia Cotacota se auia querido ausentar de la dicha prouincia por los malos tratamientos que les hazia la gente que por alli yuan a las dichas prouincias de Chile y el dicho Joan Uelasquez fue parte para tornar a traer de paz los dichos yndios e all dicho cacique con su yndustria e buenos medios e ayudo mucho a hazer aquella jornada al dicho gouernador e poblo los dichos yndios en el camino real donde antes solian estar poblados y en parte comoda para donde los pasageros se abrigassen lo qual todo fue de mucho efeto para el buen auiamiento del dicho don Garcia y se aseguro el dicho camino en tal manera que el dia de oy caminan por el los españoles seguramente lo qual todo saue e uio este testigo porque se hallo presente a todo ello en compañia del dicho Joan Velasquez y esto responde a esta pregunta.

8. A la otaua pregunta dixo que en alguna remuneracion de lo mucho que el dicho Joan Velasquez a hecho a su majestad con sus armas y cauallos y en especial en traer de paz // 
[f. 68r]

los dichos yndios de Atacama y asegurar aquel passaxe que es muy ymportante para las prouincias de Chile e Tucuman el dicho marquez de Cañete visorrey que fue destos reynos le encomendo el dicho repartimiento de yndios de Atacama e le hizo corregidor de la dicha prouincia para que con su buena yndustria los acauasse de pacificar y asegurasse aquellos passos e tuviessen justicia e amparo los dichos yndios el qual con el dicho cargo estuuo en la dicha prouincia el tiempo del dicho año y medio poco mas o menos haziendo todo lo demas que la pregunta dize y esto saue desta pregunta porque lo uio ser e passar ansi y se remite a la çedula de encomienda e titulo de corregimiento que en la pregunta se haze mencion.

9. A la nouena pregunta dixo que segun este testigo en los caciques e yndios del dicho repartimiento e prouincia le an tenido e tienen tanto amor y uoluntad all dicho Joan Velasquez a caussa de los muchos y buenos tratamientos que del an resceuido y dadiuas e otras cossas este testigo entiende que mediante lo susso dicho los dichos yndios //

\section{[f. $68 \mathrm{v}$ ]}

an sustentado la paz y an estado y estan quietos y pacificos e que si el dicho Joan Uelasquez no estuuiera de por medio segun son de uelicossos los dichos yndios y estar como estan sus comarcanos con quien ellos tratan todos yndios de guerra y uelicossos se ouieran alçado y reuelado como lo estauan de antes y esto responde a esta pregunta.

11. A las onze preguntas dixo que como dicho tiene este testigo saue que mediante los muchos y buenos tratamientos dadiuas y regalos que el dicho Joan Uelasquez Altamirano a hecho y haze a los yndios de la dicha prouincia de Atacama y auerlos sustentado con esto en la paz no les a lleuado ni lleua mas tasa ni tributo de la que ellos buenamente an podido dar e anssi este testigo entiende se le deueran cantidad de pessos de oro de la dicha tassa porque segun este testigo a entendido del dicho Joan Velasquez mas a pretendido dellos su quietud e sosiego y asegurar aquel camino y que los dichos yndios oigan la doctrina cristiana e las demas cossas que la pregunta dize que no intereses de pesos // [f. 69r]

de oro ni otra cossa y esto responde a esta pregunta.

12. A las doze preguntas dixo que durante el tiempo que a que el dicho Joan Uelasquez a tenido en encomienda el dicho repartimiento e yndios de Atacama siempre a tenido sacerdote con ellos para que los enseñe e yndustrie en las cossas de la fee y que a ydo el dicho Joan Uelasquez perssonalmente a uissitallos cuyo camino desde esta prouinçia es de los trauajossos y riesgo que dize la pregunta por caussa de las grandes nieues y despoblados e por las demas razones que en la dicha pregunta se declaran que es y passa ansi por lo cual el dicho Joan Uelasquez no a podido dexar de correr riesgo de su vida porque por la [sic] mayor tiempo del año estan los caminos cerrados de nieue donde se passa gran trauaxo de las vidas y esto saue desta pregunta porque a andado y caminado el dicho camino en compañia del dicho Joan Uelasquez muchas vezes.

13. A las treze preguntas dixo que este testigo tiene all dicho Joan Uelasquez Altamirano por buen cristiano temeroso de Dios e de su conciencia y hombre asentado //

[f. 69v]

quieto y pacifico e tal perssona como la pregunta lo dize y que siempre a tenido especial cuydado en la doctrina y conuercion de los naturales del dicho repartimiento e que en presencia deste testigo en la dicha prouincia se bautizaron y casaron muchos yndios e niños como la pregunta lo dize y que ansi mismo uio que el padre Crispoual Diaz de los Santos como cura de los dichos yndios casso y bautizo muchos de los caciques y principales para lo qual el dicho Joan Uelasquez lleuo a la dicha prouincia a su costa e minssion all dicho clerigo en todo lo qual a hecho mucho seruicio a Dios nuestro señor y a su magestad e los caciques principales e yndios despues que estan encomendados en el dicho Joan Uelasquez an uenido y bienen a esta ciudad e prouincia a sus contrataciones y este testigo a hablado ansi en Porco como en Potossi muchas vezes a los dichos caciques e yndios por que los conoce por auer estado en la dicha prouincia e que estan quietos y pacificos y en doctrina cristiana como la pregunta lo dize y esto saue e responde a ella. 
14. A las catorze preguntas dixo que despues que el dicho Joan Uelasquez Altamirano //

[f. 70r]

a tenido e tiene en encomienda los dichos yndios siempre en esta ciudad a tenido e tiene cassa poblada y familia y aderesço de armas y cauallos e que a salido muchas vezes de su cassa y ciudad en acompañamiento del señor pressidente contra los chiriguanaes que estan de guerra que uenian a los terminos desta ciudad a la desasosegar haziendo muchas muertes y robos allende de otras jornadas que se an ofrescido y que a todo a estado tan a punto en las cossas tocantes all seruicio de su magestad e se le an encomendado las dichas jornadas e otras cossas como a perssona de confiança y celoza del real seruicio e que no saue ni a uisto ni oydo dezir que se le aya dado socorro ni ayuda de costa para las dichas jornadas antes le a uisto yr a su costa e minssion y con sus armas y cauallos en todo lo qual no a podido dexar de gastar cantidad de dineros por ser esta prouincia muy cara de mercadurias e otras cossas y esto saue desta pregunta por lo auer uisto ser y passar anssi. [...]

\section{[f. 70v]}

16. A la diezeseis preguntas dixo que lo que dicho tiene de susso en este su dicho es la verdad publico e notorio para el juramento que tiene fecho e firmolo de su nombre Sancho de Figueroa ante mi Tristan Sanchez.

[al margen: testigo]

E despues de lo susso dicho en la dicha ciudad de La Plata en este dicho dia diez //

\section{[f. 71r]}

y siete de jullio del dicho año el dicho Joan Velasquez Altamirano pressento por testigo para la dicha ymformacion a Pedro de Cuellar estante en esta corte del qual fue tomado e resceuido juramento en forma de derecho sobre una señal de cruz segun de susso e auiendo jurado e siendo preguntado por las preguntas del dicho ynterrogatorio dixo lo siguiente:

1. A la primera pregunta dixo que conoce all dicho Joan Uelasquez Altamirano de veynte años a esta parte poco mas o menos en este rey no del Piru. [al margen: generales]

Preguntado por las preguntas generales de la ley dixo que es de hedad de treinta e dos años poco mas o menos y que no le tocan las generales. $[\ldots]$

[f. 73v]

7. A la septima pregunta dixo que a oydo dezir lo contenido en la pregunta a perssonas de cuyos nombres no se acuerda y en especial a Sancho de Figueroa y dello a sido y es cossa publica en esta prouincia sin auer cossa en contrario.

8. A la otaua pregunta dixo que el marques de Cañete uissorei que fue destos reinos ymformado de quan leal seruidor de su magestad auia sido y era el dicho Joan Velasquez le encomendo la mitad de los yndios de la dicha prouincia de Atacama y le hizo corregidor della con cierto salario por año donde ressidio cierto tiempo y que en lo del salario y lo demas se uera por la dicha cedula de encomienda y titulo de corregimiento a lo qual se remite.

9. A la nouena pregunta dixo que este testigo a uisto que despues que uinieron all gouierno deste reino el conde de Nieua e comissarios a ydo por corregidor de la dicha prouincia de Atacama personas particulares por lo qual se entiende y esta claro se a hecho corregimiento ordinario y esto responde. //

[f. 74r]

10 10. A la dezima pregunta dixo que es cossa publica y ansi lo entiende este testigo auer el dicho Joan Uelasquez Altamirano regalado mucho los yndios de aquella prouincia e dadoles muchas dadiuas de presseas e otras cossas y que ansi por este respeto entiende este testigo los dichos yndios an sustentado la paz siendo como son yndios tan uelicossos y estar sus comarcanos de guerra y esto responde a la pregunta.

11. A la onze preguntas dixo que este testigo a oydo dezir lo contenido en la pregunta all dicho Joan Uelasquez e que por las razones que tiene dichas y en la pregunta se contienen este testigo entiende el dicho Joan Uelasquez no cobrara mas tributos de los dichos yndios de lo que ellos buenamente pueden pagar y esto responde. 
12. A las doze preguntas dixo que lo conthenido en la dicha pregunta es cosa publica e notoria en esta prouincia e por tal lo a oydo dezir este testigo sin auer cossa en contrario.

13. A las treze preguntas dixo queste testigo tiene all dicho Joan Uelasquez Altamirano //

[f. 74v]

por buen crisptiano temerosso de Dios e de su conciencia e muy quieto y pacifico y de buena uida y fama e tal perssona como la pregunta lo dize y que los yndios de la dicha prouincia an estado desde el tiempo que el dicho Joan Velasquez los traxo de paz a esta parte y hasta este punto quietos y pacificos y bienen a Potossi y esta ciudad muchas vezes e ressiden en ellos muchos yndios e tienen sus contrataciones como los demas yndios que estan debaxo del real dominio e que teniendo como de ordinariamente an tenido sacerdotes en sus pueblos que an entendido en su dotrina e pulicia no pueden dexar de ser bien doctrinados e yndustriados en las cossas de la santa fee catholica y esto responde a esta pregunta e dello es cossa publica e notoria en esta ciudad y prouincia.

14. A las catorze preguntas dixo queste testigo saue e a uisto que el dicho Joan Uelasquez Altamirano despues que tiene en encomienda los dichos yndios a tenido e tiene en esta ciudad cassa poblada con armas y cauallos e otros aderezos //

\section{[f. 75r]}

necessarios muy honrrossamente y a salido en vezes desta ciudad ansi en compañia del señor pressidente a la jornada de los chiriguanaes e a otras cossas tocantes all seruicio de su magestad e que por ser el dicho Joan Uelasquez tan çelozo del seruicio de su magestad y hombre tan aparexado e diligente en todo lo que se le quissiere encargar e de mucha confiaça se le an encargado jornadas y cosas de ynportancia por esta real audiencia e por las justicias que an sido desta prouincia las quales dichas jornadas las a hecho todas a su costa y minssion porque nunca jamas a oydo dezir que se le ouiesse dado socorro ni ayuda de costa alguna y esto saue desta pregunta e responde a ella. [...]

\section{[f. 75v]}

16. A la diez e seis preguntas dixo que dize lo que dicho tiene lo qual es la uerdad publico e notorio para el juramento que fecho tiene e firmolo de su nombre Pedro de Cuellar ante mi Tristan Sanchez.

Muy poderosso señor Joan Uelasquez Altamirano cerca de la prouança de mis seruicios que ante vuestra alteza hago digo que por carta receutoria desta real audiencia se hizo en la villa de Potosi esta prouança la cual viene cerrada //

\section{[f. 76r]}

y sellada de la qual y de vna carta mesiua que el marques de Cañete vuestro vissorrey me escriuio firmada de su nombre hago de todo pressentacion.

A vuestra alteza pido y supplico lo aya todo por pressentado e lo mande juntar con la prouança que en esta corte tengo hecha y que vuestro secretario me lo de todo debajo de vn signo en publica forma Joan Uelasquez Altamirano.

En la ciudad de La Plata diez e siete dias del mes de agosto de mil e quinientos y setenta años ante los señores pressidente y oidores estando en audiencia publica la pressento el contenido y los dichos señores la mandaron que se ponga con la prouança principal e que se le de todo en publica forma Tristan Sanchez.

[al margen: aut. a]

Don Phelipe por la gracia de Dios ... [etc.] //

[f. 76v]

A todos los corregidores alcaldes mayores e ordinarios $\mathrm{y}$ otros juezes e justicias qualesquiera ansi de la uilla ymperial de Potossi como de otra qualquier parte ciudad parte e lugar de los nuestros reynos del Peru y a cada vno y qualquier dellos en buestro lugar e jurisdicion a quien esta carta fuere mostrada salud e gracia sepades que Joan Uelasquez Altamirano por una peticion que presento en la nuestra corte e chancilleria ante el presidente e oydores de la dicha nuestra audiencia que por nuestro mandado resside en la ciudad de La Plata de los dichos nuestros reynos del Piru nos hizo relacion diziendo que el nos auia seruido en estos nuestros reynos de 
veinte años que auia que ressidia en ellos en todo lo que se auia ofrescido a su costa e que para que nos constase dello y a vuestros [?] vissorreyes e gouernadores que ba a hazer ymformacion dello por ciertas preguntas que para ello presenta en la dicha nuestra audiençia e nos supplico e pidio por merced mandassemos hazer //

\section{[f. 77r]}

la dicha ymformacion con çitaçion del fiscal e porque algunos testigos tenia fuera desta nuestra corte le mandassemos dar nuestra carta receptoria para que ante uos se hiziesse su prouança o como la nuestra merced fuesse lo qual uisto por los dichos nuestro pressidente y oidores mandaron que se hiziesse la dicha prouança y fue acordado que deviamos mandar dar dar [sic] esta nuestra carta para vos en la dicha razon e nos tuuimoslo por bien por la qual uos mandamos que si la parte del dicho Joan Uelasquez Altamirano paresciere ante vos y uos requiriere con esta nuestra carta hagares uenir e parescer ante uos a todos los testigos de quien dixeren que se entiende aprouechar para la dicha prouança y ansi ante uos parescidos por ante un escriuano publico de la ciudad uilla y lugar donde se os pressentare tomeis e resceuais dellos y de cada uno dellos sus dichos y depussiciones preguntandoles ante todas cossas que edad an y si son parientes del dicho Joan Uelasquez Altamirano e por las demas preguntas generales de la ley e por los del ynterrogatorio que ante uos sera presentado que mandamos vaya firmado de Tristan Sanchez escriuano de camara de la dicha //

\section{[f. 77v]}

Real audiencia y all testigo que dixere que saue la pregunta preguntalle e como la saue y all que dixere que la cree que como y por que la cree y al que dixere que la oyo dezir que a quien quando y donde y que tanto tiempo a por manera que cada testigo de razon de su dicho y depusicion y hecho la dicha prouança escrita en limpio firmada de vuestro nombre signo e firmada del escriuano publico ante quien passare serrada e sellada le dareis y entregareis a la parte del dicho Joan Uelasquez Altamirano para que la pressente donde uiere que le conuiene pagando por ello los derechos que justamente deuiere conforme all arancel de nuestros reynos lo qual hareis asentar al pie del signo e la razon porque los lleuais e de quien de los quales dareis carta de pago a parte a la perssona que os los pase e no fagades ende al so pena de la nuestra merced e de quinientos pesos de oro para la nuestra camara dada en la ciudad de La Plata a ueinte e ocho dias del mes de junio de mil e quinientos y setenta años el licenciado Pedro Ramirez el licenciado Antonio Lopez de Haro yo Tristan Sanchez //

\section{[f. 78r]}

escriuano de camara de su catolica magestad la fize escriuir por su mandado con acuerdo de su pressidente e oydores chanciller Pedro de Çeuallos registrada Garçia de Esquiuel.

En la Plata dieziocho de jullio de mill e quinientos y setenta años ante mi el escriuano e testigos yusso escritos parescio pressente Joan Uelasquez Altamirano vezino desta ciudad e dixo que daua e dio su poder cumplido quan bastante de derecho se requiere a Joan Uelasquez de Açeuedo y a Francisco de Arze a ambos a dos juntamente e a cada uno por si yn solidum para que por el y en su nombre puedan pressentar esta real prouission de su magestad ante qualesquier justicias juezes y escriuanos e pressentar testigos y hazer la prouança que en ella se haze mencion e la sacar autorizada e la traer a esta corte y en razon dello hazer todos los autos e diligencias que conuengan de se hazer y que el haria siendo pressente que quan cumplido poder y la tiene para lo que dicho es o tratal [sic] y ese mesmo lo dio y otorgo con sus ynsidencias e dependencias y con libre e general administracion e los releuo en forma y para lo auer por firme //

\section{[f. 78v]}

obligo su perssona y bienes auidos e por auer a lo qual fueron testigos Gaspar Rios e Pedro Vela e Alonso Aluares estantes en esta corte y el dicho otorgante yo el escriuano conozco lo firmo de su nombre Joan Uelasquez Altamirano e yo Tristan Sanchez escriuano de camara de su catolica real magestad presente fui a lo que dicho es y lo fize escriuir e fize aqui este mi signo que es a tal en testimonio de verdad Tristan Sanchez. [...]

[Entre fs. 78v y 81v sigue un traslado del interrogatorio ya transcrito entre fs. 36r y 39r. Nota del transcriptor]

\section{[f. 81v]}

En la villa ymperial de Potossi veynte e ocho dias del mes de jullio de mill y quinientos e setenta años ante 
el magnifico señor Gonzalo Santos alcalde hordinario en esta uilla por su magestad y en presencia de mi Martin de Barrientos escriuano parescio pressente Joan Uelasquez de Aceuedo y pressento la prouission real poder e ynterrogatorio que de susso se haze mencion y pidio el cumplimiento de la dicha real prouission e por el señor alcalde vista y obedescida con el acatamiento deuido dixo que el dicho Joan Uelasquez pressente los testigos de que se entiende aprouechar e que se cumpla la dicha real prouission testigos Matheo Flores y Ouiedo Dauila //

\section{[f. 82r]}

En el dicho dia mes y año susso dicho ante el dicho señor alcalde el dicho Joan Uelasquez de Aceuedo traxo e pressento por testigo en la dicha razon all padre Esteuan Justiniano clerigo presuitero ressidente en esta uilla el qual poniendo la mano en su pecho juro yn beruo sacerdotis por el auito de San Pedro y San Pablo que resceuio e prometio de dezir verdad y a la conclucion del dicho juramento dixo si juro y amen testigos pressentes Crispoual Gonzalez e Francisco Aromo.

Y lo que dixo e depusso exssaminado por el tenor del dicho ynterrogatorio es lo siguiente:

\section{[al margen: testigo]}

En Potossi diez e siete dias del mes de jullio de mill e quinientos y setenta años el dicho Joan Uelasquez en nombre del dicho Joan Velasquez Altamirano presento por testigo en la dicha razon al padre Esteuan Justiniano clerigo presuitero el qual auiendo jurado segun forma sacerdotal e siendo preguntado por el tenor del dicho ynterrogatorio e preguntas del dixo e depusso lo siguiente: //

\section{[f. $82 \mathrm{v}]$}

1. A la primera pregunta dixo que conoçe all dicho Joan Uelasquez Altamirano y que saue que a muchos años que esta en esta tierra pero que no se saue quantos años a.

\section{[al margen: generales]}

Preguntado por las preguntas generales dixo que es de hedad de treinta e cinco años y que no es pariente del dicho Joan Uelasquez ni le va ynteresse en esta caussa. [...]
7. A la septima pregunta dixo que lo que della saue es que el testigo a oydo dezir a don Pedro e a don Martin y a don Joan Corocero caciques principales del valle de Atacama lo que la pregunta dize como en ella se contiene e que esto lo a oydo dezir este testigo a los susso dichos muchas y diuerssas vezes e que ansi mesmo lo a oydo dezir a muchas perssonas españoles en estas partes e que esto responde. //

\section{[f. 83r]}

8. A la otaua pregunta dixo este testigo que lo contenido en la pregunta lo a oydo dezir a los dichos caciques de Atacama en el dicho valle y que esto responde a ella.

9. A la nouena pregunta dixo este testigo que saue la pregunta como en ella se contiene preguntado como la saue dixo que porque este testigo a ressidido tiempo de mas de seis años en el dicho ualle de Atacama y en el dicho tiempo a uisto proueidos en el corregidores por los que an gouernado y que agora all presente esta en el dicho corregimiento vn don Francisco Lobato y que esto responde.

10. A la dezima pregunta dixo que lo que della saue es que algunos corregidores que en tiempo que este testigo ressidia por cura e vicario del dicho ualle les a puesto en condiçion de alçarsse por malos tratamientos e molestias que se les hazian lo qual efetuaran e pusieran por obra si el dicho Joan Uelasquez Altamirano por buenos medios y dadiuas no les aplacara e quietara e que siempre lo ha hecho e haze con los dichos yndios por cuyo buen tratamiento no se han alçado //

\section{[f. $83 \mathrm{v}]$}

y que esto responde a esta pregunta.

11. A la onzena pregunta dixo que lo que desta pregunta saue es que el dicho Joan Uelasquez no resciue mas tributo ni tanto de lo que los dichos yndios le quieren dar porque de dos mill e tantos pessos que son obligados a le dar conforme a su tassa no le dan lo que son obligados sino que antes le deuen mucha cantidad de pessos e que lo disimula con ellos por no apretarlos de arte que se alçen e inquieten por ser como dicho tiene gente muy velicossa y confinar con Calchaqui y otras comarcas de gente no reduçida a paz y que esto responde. 
12. A las doze preguntas dixo que lo que della saue es que abra ocho años poco mas o menos que a este testigo el dicho Joan Uelasquez dio en la ciudad de Lima vna barra de plata ensayada e marcada para en quenta de seiscientos pesos que le daua en cada vn año por razon de la dicha doctrina e que saue que en el dicho tiempo que all dicho Joan Velasquez no dauan los yndios tributo ni acostamiento //

\section{[f. 84 r]}

alguno y que anssi se desconto la dicha barra en la dicha doctrina e que demas desto saue este testigo que el dicho Joan Uelasquez a ido al dicho ualle de Atacama en tiempo de gran riesgo ansi por estar ynquietos los dichos yndios como por los brauos despoblados que ay en el dicho camino el qual e dicho uiaxe hizo el dicho Joan Uelasquez a yntersseción deste testigo por auisso que le dio estar ynquietos los dichos yndios y en punto de se reuelar con la qual dicha yda el dicho Joan Uelasquez hizo mucho efeto porque los asento y allano y torno a reduzir en el estado en que estan agora y que esto responde a esta pregunta.

13. A las treze preguntas dixo que la saue como en ella se contiene preguntado como la saue dixo que porque lo uio ser y pasar como en ella se contiene y que esto responde a esta pregunta.

14. A las catorze preguntas dixo que saue este testigo que el dicho Joan Uelasquez Altamirano sustenta su vezindad armas y cauallos como hombre de republica e seruidor //

\section{[f. 84v]}

de su magestad e que saue que a ydo en seruicio de su magestad muchas vezes a los chiriguanaes donde con sus armas y cauallos a su costa e minsion segun y como la pregunta dize a que esto responde $[\ldots]$.

17. [sic] A la diez e siete preguntas dixo que saue que todo lo susso dicho es publico e notorio e publica voz e fama entre todos lo que desto tienen noticia e que esto es la uerdad para el juramento que hizo e firmolo de su nombre siendole leydo el dicho su dicho dixo que en el //

\section{[f. 85r]}

se afirmaua e ratificaua e lo firmo de su nombre Esteuan Justiniano Martin de Barrientos escriuano publico.

Y despues de lo susso dicho en la dicha uilla de Potossi a ueinte e nueue dias del dicho mes de jullio del dicho año ante el dicho señor alcalde parescio el dicho Joan Uelasquez en el dicho nombre e dixo que no quiere pressentar mas testigos pidio se le mande dar lo que este testigo que tiene pressentado a dicho e declarado y el señor alcalde se lo mando dar conforme a lo mandado por la dicha prouission real y en ello ynterpusso su autoridad e decreto judicial e lo firmo de su nombre Gonçalo Santos yo Martin de Barrientos escriuano de su magestad de pedimento y de mandamiento del dicho señor alcalde que aqui firmo lo fize escreuir en diez foxas de pliego conste en que va mi signo en testimonio de uerdad Martin de Barrientos escriuano publico.

[al margen: carta del marques]

Magnifico señor el señor licenciado Altamirano me escriuio dende Arequipa quando yua alia arriba e me enbio una carta //

\section{[f. $85 \mathrm{v}$ ]}

que le escriuistes acerca de los yndios de Atacama yo me e holgado de uella e de sauer que uengan de paz e se bautizen y oss encargo mucho que pues aueis començado tan buena obra que la lleueis adelante yo enbio el perdon e las cartas que enbiastes a pedir y auissarmeis [sic] señor de como lo hazen y de todo lo de por alla nuestro señor vuestra magnifica perssona guarde de Los Reyes diez y ocho de nouiembre de mill e quinientos y cinquenta y seis.

Estos yndios se pongan en cabeça de su magestad que conuiene ansi que vuestra remuneracion aca se hara en cossa mejor e mas asentada a lo que vuestra merced mandare el marques.

Al magnifico señor Joan Uelasquez Altamirano en la uilla de La Plata uissorey muy poderosso señor Joan Uelasquez Altamirano en la prouança de seruicios que estoy haziendo digo que me conuiene exssaminar algunos testigos que estan fuera desta corte pido e 
suplico a vuestra alteza me mande dar carta receptoria y vn traslado del dicho ynterrogatorio para //

\section{[f. 86r]}

que se exssaminen los testigos para lo qual etc.

En la ciudad de La Plata a veinte y ocho dias del mes de junio de mill y quinientos e setenta años ante los señores pressidente y oidores estando en audiencia publica la pressento el contenido y los dichos señores mandaron que se le de la carta receptoria que pide Tristan Sanchez. Muy poderoso señor Joan Uelasquez Altamirano serca de la prouança de seruicios que hago de lo que e seruido a vuestra alteza en estos reynos hago presentacion desta cedula original de la encomienda de yndios de Atacama que me hizo el marques de Cañete vuestro vissorey que fue destos reynos y desta prouança que hize ante el mariscal Alonso de Aluarado de lo que serui a vuestra alteza en la alteracion de don Sebastian de Castilla y prission de Egas de Gusman.

A vuestra alteza pido y suplico le aya por pressentada e mande se ponga con la prouança e para ello etc., a Joan Uelasquez Altamirano. //

\section{[f. 86v]}

En la ciudad de La Plata a primero dia del mes de jullio de mil e quinientos e setenta años ante los señores pressidente y oidores en audiencia real la pressento el contenido e los dichos señores auieron por pressentado lo contenido en esta peticion y que se junte con la ymformacion e mandaron dar traslado all fiscal Tristan Sanchez.

\section{[al margen: notificacion]}

En este dicho dia lo notifique all licenciado Rauanal fiscal de su magestad que lo oyo Tristan Sanchez.

\section{[al margen: çedula]}

Don Hurtado de Mendoza marques de Cañete guarda mayor de la ciudad de Cuenca vissorrey e capitan general en estos reynos e prouincias del Piru por su magestad etc. por quanto Joan Uelasquez Altamirano me hizo relacion que es a ocho años poco mas o menos tiempo que esta en estos reinos donde a seruido a su magestad en lo que se a ofrescido y particularmente que al tiempo que don Sebastian de Castilla y Egas //

\section{[f. 87r]}

de Guzman se alçaron en la ciudad de La Plata y asiento de Potossi prouincia de los Charcas contra el seruicio de su magestad Alonsso de Arriaca caudillo del dicho Egas de Guzman fue con quinze hombres arcabuçeros all asiento de Porco e le prendio a el y a otras perssonas e los truxo all dicho asiento de Potossi donde el dicho Egas de Guzman le quito sus armas y le pusso pena de muerte que no saliese del dicho asiento y que desde a ciertos dias Antonio de Luxan le llamo y entraron en el apossento donde estauan pressos Martin de Almendras y Gomes de Solis y Joan Bendrel y prendieron all dicho Egas de Guzman y soltaron los dichos pressos e ayudo hasta que se hizo justiçia del e de otros aliados suyos y se reduxo el esquadron que tenia hecho al seruiçio de su magestad y que all tiempo que el mariscal Alonsso de Aluarado fue a el dicho asiento a entender en el castigo y allanamiento del susso dicho estuuo en su acompañamiento y por su mandado fue a las prouincias de los chiriguanaes y truxo pressos a Joan de Santa Cruz e otros //

\section{[f. 87v]}

delinquentes y auiendosse entendido en la dicha prouincia de los Charcas el alçamiento que Francisco Hernandez Giron vezino de la ciudad del Cusco e otros hizieron en ella contra el seruicio de su magestad uino en acompañamiento del dicho mariscal y del estandarte rreal que traia con sus armas y cauallos y truxo a su costa diez soldados con sus armas desde el dicho asiento de Potossi a la ciudad del Cusco y de alli hasta el ualle de Chuquinga donde se hallo en el requentro y batalla que se dio al dicho Francisco Hernandez Giron y fueron desuaratados e salio rouado de todo quanto auia lleuado que ualia cantidad de pesos de oro y acudio all campo de su magestad que lleuauan los oydores desta real audiencia contra el dicho Francisco Hernandez y topo a Gomez de Solis qua yua proueido por capitan de las ciudades de Arequipa arriba y se fue con el y llegados a la dicha ciudad de Arequipa le nombro capitan de su magestad $y$ dio a su cargo toda la gente que auia en ella donde se torno a aderesçar de armas //

\section{[f. 88r]}

y cauallos y se hallo al tiempo que Joan de Piedra Hita maestre de campo del dicho Francisco Hernandez entro en la dicha ciudad y los desuarato y le roauaron lo que tenia y que por mandado del licenciado 
Altamirano oydor en la real audiencia que resside en esta ciudad de Los Reyes e justicia mayor de las dichas prouincias de los Charcas fue el ualle de Tarixa donde estaua Joan Nuñez de Prado con setenta hombres y entre ellos algunos delinquentes e los desuarato e traxo presso a Joan de Santa Cruz de quien se hizo justiçia y que por mi orden fue a la prouincia de Atacama con ueinte hombres y truxo de paz a la ouediencia de su magestad los naturales della y [testado: auiendo] auio a don Garcia de Mendoça gouernador de las prouincias de Chile e la gente que lleuaua donde passo trabajos e hizo muchas costas en todo lo qual a seruido a su costa como bueno y leal uasallo de su magestad sin auer desseruido en cossa alguna y que hasta agora no se le a hecho gratificacion dello y me pidio e suplico que atento a lo susso dicho //

\section{[f. $88 \mathrm{v}$ ]}

le hiziesse la merced que fuesse seruido con que se sustentasse e por mi uisto por la presente en nombre de su magestad e por uirtud de su real poder que para ello tengo su thenor del qual es el que se sigue:

Don Carlos por la diuina clemençia Enperador semper agusto rey de Alemania doña Joana su madre y el mismo don Carlos por la gracia de Dios reyes de Castilla de Leon de Aragon de las dos Cicilias de Jerussalem de Nauarra de Granada de Toledo de Ualencia de Galicia de Mallorcas de Seuilla de Cerdeña de Cordoua de Corcega de Murcia de Jaen de los Algarues de Algecira de Gibraltar de las islas de Canaria de las Yndias e Tierra firme del mar oceano conde de Flandes y de Tirol etcetera por quanto nos auemos proueido por nuestro vissorey e capitan general de las prouincias del Piru y pressidente de la audiencia real que en ella resside a vos don Hurtado de Mendoça marques de cañete y en las prouisiones que dello se os an dado no se os da poder y facultad para encomendar los yndios //

\section{[f. 89r]}

que en las dichas prouincias vacaren ansi como lo an hecho los nuestros gouernadores que an sido dellas y queriendo proueer en ello de manera que las perssonas que nos an seruido en el descubrimiento y poblacion de la dicha tierra y en ellas nos siruieren en lo que se ouiere ofrescido y ofresciere sean gratificados y reciuan merced visto por los de nuestro conssejo de las Yndias fue acordado que deuiamos mandar dar esta nuestra carta para vos en la dicha razon e nos tuuismoslo por bien por la qual damos licencia poder y facultad a uos el dicho don Hurtado de Mendoça marques de Cañete para que por el tiempo que nuestra voluntad fuere los yndios que ouieren vacos quando uos llegaredes a las dichas prouincias que no esten encomendados a personas particulares e los que vacaren durante el tiempo que uos en ellas estuuieredes los podais encomendar y encomendeis a los españoles que en ellas ressiden e ressidieren segun e como lo hizieron e pudieron hazer por uirtud de los poderes que de nos //

\section{[f. 89v]}

para ello tenian el marquez don Francisco Piçarro nuestro gouernador que fue de las dichas prouincias y el licenciado Gasca nuestro Pressidente que fue de la real audiencia dellas y el nuestro vissorey don Antonio de Mendoça e que los tengan e se siruan y aprouechen dellos conforme a las ordenanças que para su buen tratamiento estan hechas y los que se hizieren de aqui adelante y de la forma y manera e condicion con que los an tenido e tienen las otras perssonas que tienen yndios encomendados en ellas y en las tales encomiendas preferireis a los primeros conquistadores desas prouincias que estuuieren syn yndios e depues dellos a los pobladores cassados que tuuieren calidades para los tener y antes que hagais las dichas encomiendas de los yndios que vacaren proueereis que se tasen los tributos que an de dar conforme a las nueuas leyes y a las prouissiones y çedulas por nos despues dello dadas //

\section{[f. 90r]}

serca de la dicha tasacion para que aquello que fuere tassado lleuen los tales encomenderos e no otra cossa alguna que para ello vos damos poder cumplido con todas sus ynsidencias e dependencias anegidades [sic] y conegidades dada en nuestra uilla de Brucelas a diez dias del mes de março de mil y quinientos e cinquenta e cinco años yo el Rey yo Francisco de Erasso secretario de su sesarea y catholicas magestades la fize escriuir por su mandado el marques el liçençiado Tello de Sandoual el licenciado don Joan Sarmiento el doctor Vasquez el licenciado Uillagomez registrada Ochoa de Luyando chanciller Martin de Ramuyn. Encomiendo en vos el dicho Joan Uelasquez Altamirano en la prounçia de Atacama la mitad del repartimiento de yndios de la dicha prouincia que en compañia de Francisco de Ysasaga difunto y por su muerte don Pedro de Cordoua que estan uacos por dexacion que dellos // 


\section{[f. 90v]}

hizo el dicho don Pedro de Cordoua con el cacique principal que se dize don Joan Cotocotar que esta en Atacama la grande y don Francisco Pachagua para que por indiuissos los tengais en encomienda en compañia del dicho Francisco de Ysasaga con todos sus principales e yndios naturales e mitimaes pueblos y estancias a ellos subjetos e pertenecientes bien ansi segun que los tuuieron encomendados los dichos Pedro de Ysasaga y don Pedro de Cordoua en uirtud de las cedulas de encomienda que dellos tuvieron y ansi mismo uos encomiendo los yndios que estan en el puerto del dicho ualle de Atacama que uos el dicho Joan Uelasquez truxisteis de paz e hizisteis poblar que andauan derramados con los caciques principales dellos para que los tengais e poseais ayais cobreis y gozeis los tributos de los naturales del dicho repartimiento vieren de dar conforme a la tassa que dellos se hiziere desde el dia que tomaredes la posesion de los //

\section{[f. 91r]}

dichos yndios en adelante en alguna gratificacion de lo que aueis seruiçio a su magestad $y$ en el entretanto que se haze la dicha tassa vos encargo y mando que no pidais ni lleueis tributos excessiuos ni mas de aquellos que buena e justamente y sin uexacion deuieren y pudieren dar para ayuda a vuestra comoda sustentacion con aperceuimiento que uos hago que si en ello ecedieredes se os mandara descontar la tal demassia para en parte de pago de lo que adelante ouieren de dar conforme a la tassa que se hiziere de los dichos tributos e con que no os siruais de los indios por bos ni por ynterpossitas perssonas de ningun seruicio perssonal en vuestra cassa ni otras haziendas grangerias ni obras sin espressa liçençia mia y con voluntad dellos e pagandosselo so las penas conthenidas en las hordenanças prouissiones y cedulas reales que sobre ello estan dadas y con que los trate bien y procure su conseruacion multiplicacion anparo y defensa e los haga doctrinar //

\section{[f. 91v]}

en las cossas de nuestra santa fee catholica ley natural y buena pulicia e si en ello algun descuydo ouiere cargue sobre su conciencia y no de su magestad ni mia que en su real nombre uos encomiendo e por la pressente mando a Antonio de Hosnayo corregidor por su magestad de la ciudad de La Plata prouincia de los Charcas y alcaldes hordinarios della e a cada vno y qualquier dellos que luego que por parte del dicho Joan Uelasquez Altamirano fuere pedida posesion de los dichos yndios se la den en forma e no se la pudiendo ellos dar perssonalmente prouean de vna perssona que la de y dada le anparen y defiendan en ella e no conssientan que della sea despoxado sin primero ser oido e uencido por fuero y por derecho so pena de cada mill pessos de oro para la camara e fisco de su magestad fecho en Los Reyes a ueinte dias del mes de hebrero de mill y quinientos y sesenta años el marques por mandado de su excelencia Pedro de Avendaño //

\section{[f. 92r]}

En el asiento de minas de Potossi termino e jurisdicion de la ciudad de La Plata en seis dias del mes de junio del año del señor de mill y quinientos e sesenta años ante el muy magnifico señor Antonio de Hosnayo corregidor e justicia mayor en la dicha ciudad e por ante mi el escriuano e testigos parescio pressente Aluaro de Mendoça en nombre y en voz de Joan Velasquez Altamirano e por uirtud de su poder para este efeto e otras cossas de que hizo demostracion signado de Gaspar Hernandez escriuano publico e del cabildo de la ciudad de Arequipa hecho y otorgado en ella a ueinte e siete de abril deste dicho año e pressento esta cedula de encomienda y prouission del muy exselente señor marques de Cañete vissorey y capitan general en este reyno por su magestad y con ella requirio al dicho señor corregidor para que en el dicho nombre le den y entreguen la posesion del dicho repartimiento de Atacama y pueblos que estan en el puerto e que se la de en vn yndio natural del dicho repartimiento que estaua pressente y le defienda e ampare en ella y lo pidio por //

\section{[f. 92v]}

testimonio el dicho señor corregidor dixo que estaua presto de dar la dicha posesion e luego el dicho señor corregidor por lengua de Pedro de Cabrera ynterprete pregunto all dicho yndio que como se llamaua e de donde era natural el qual respondio por la dicha lengua llamarse Catapara e ser cristiano e llamarse Joan e ser natural de Atacama la grande del ayllo de don Joan Cotacota el dicho señor corregidor le dio a entender por la dicha lengua como su excelencia auia hecho merçed all dicho Joan Velasquez Altamirano de le encomendar la mitad del dicho repartimiento con los pueblos del puerto de Atacama e que le queria dar la posesion e luego el dicho señor corregidor tomo por la mano all dicho yndio e lo dio y entrego all 
dicho Aluaro de Mendoça e dixo que en nombre del dicho Joan Velasquez Altamirano e para el le daua e dio la posesion real corporal autual vel cassi del dicho repartimiento e pueblos en esta prouission conthenidos en el dicho yndio en bez y en nombre de todos los demas caciques //

\section{[f. 93r]}

principales e yndios del dicho repartimiento esto constando que el dicho Joan Uelasquez Altamirano tenga poblada la cassa y uezindad de la ciudad de La Plata con su perssona armas y cauallo conforme a lo que su magestad tiene mandado e con este aditamiento lo daua e dio la dicha posesion para que tenga la encomienda del dicho repartimiento conforme a esta prouission y el dicho Aluaro de Mendoça tomo el dicho yndio de mano del dicho señor corregidor e dixo que en vez y en nombre del dicho Joan Uelasquez Altamirano y para el resceuia e resceuio la dicha pocession en el dicho yndio en bez y en nombre de los demas caciques principales e yndios del dicho repartimiento e se paseo con el dicho yndio trayendolo de la mano de una parte a otra y de otra a otra e le dixo que se fuesse con el todo lo qual dixo que se hazia e hizo en señal de posesion y el dicho señor corregidor dixo que le amparaua y amparo en la dicha posesion e aperceuia e mandaua que ninguna persona se la ynquietasse ni perturbasse hasta ser oydo por fuero //

\section{[f. 93v]}

y por derecho vencido so las penas en que yncurren los que quebratan [sic] posesion dada por auturidad de justicia e mas de quinientos pessos para la camara de su majestad y el dicho Aluaro de Mendoça en nombre del dicho Joan Uelasquez Altamirano de como auia tomado la dicha posesion quieta e pacificamente sin contradicion de persona alguna dixo que lo pedia e pidio por testimonio a mi el dicho escriuano e yo el dicho escriuano doy fee que no ubo contradicion aunque lo pregunte a los presentes y el dicho señor corregidor lo firmo a todo lo qual fueron pressentes por testigos el licenciado Martinez y Crispoual Diaz de los Santos clerigos y Domingo de las Cassas estantes en este asiento e yo el sobre dicho Lazaro del Aguila y escriuano de su magestad escriuano publico e del cauildo de la dicha ciudad de La Plata y asiento de Potossi y sus terminos e jurisdicion por su magestad fui presente a lo que dicho es e de ello doy fee e lo fize escreuir e fize mi signo a tal en testimonio //

\section{[f. 94r]}

de uerdad Lazaro del Aguila escriuano publico y del cauildo.

[entre fs. 94r y 106r sigue la probanza de meritos de Joan Velasquez Altamirano ante el mariscal Alonso de Alvarado, hecha en Potosi en 1553, sobre sus actuaciones durante las sublevaciones de Sebastian de Castilla y Egas de Guzman y el alzamiento de Francisco Hernandez Girón. Nota del transcriptor].

[f. 106r]

[al margen: peticion]

Muy poderosso señor don Francisco Altamirano vezino y regidor perpetuo desta ciudad digo que vuestra alteza a mandado hazer de oficio ymformacion de los meritos y seruicios del capitan Joan Uelasquez Altamirano mi padre y de los que e fecho a vuestra alteza y de los seruicios del dicho mi padre se hizo en esta real audiençia ymformacion por junio de setenta años como dello consta de que hago pressentacion y para que sobre todo se de el parescer por vuestro pressidente e oydores conforme a la nueua //

\section{[f. 106v]}

cedula de vuestra real perssona a vuestra alteza suplico mande juntar la dicha ymformacion con la que all pressente se ua haziendo para que sobre todo se de el dicho parescer pues se hizo la dicha ymformacion en esta real audiencia y della consta de los seruicios del dicho mi padre hasta el tiempo dicho e pido justicia etcetera el liçenciado Antonio de Escobar don Francisco Altamirano.

[al margen: decreto]

Juntese con la que se haze de oficio.

En La Plata a ueinte e siete de jullio de mill quinientos y nouenta e seis años los señores pressidente $\mathrm{e}$ oydores proueyeron lo decretado de susso Joan de Lossa.

[al margen: peticion]

Muy poderosso señor don Francisco Altamirano vezino y regidor perpetuo desta ciudad digo que por vuestra alteza sea mandado hazer de oficio ymformacion de los meritos y seruicios del capitan Joan 
Uelasquez Altamirano mi padre e de los seruicios que yo e fecho a vuestra alteza e para que conste a vuestra real perssona como los yndios en que subcedi en la segunda uida que tubo en encomienda el dicho mi padre en Atacama no an rentado ni rentan hasta el dia de oy cossa alguna conuiene que sobre ello //

\section{[f. 107r]}

declaren los testigos que de oficio se resciuieren para la dicha ymformacion demas de que juro a Dios y a esta cruz que los dichos yndios de mi encomienda no han tributado ni el dia de oy tributan ni dan aprouechamientos algunos porque siempre an estado ynquietos e no muy pacificos e que no se an podido reducir por estar en partes tan remotas y apartadas como en la prouincia de Atacama que hasta agora a sido nescesario sustentar los dichos yndios con buenos tratamientos para que solo se dexen doctrinar que si se les pidiessen pagassen tributos se remontarian e leuantarian de suerte que en ninguna manera dan prouecho ni rentas.

A vuestra alteza suplico que conforme a lo que dicho es que es notorio a vuestro pressidente y oidores y all juramento que hago en forma en razon de no tributar los dichos yndios se sirua a dar el parescer en conformidad de lo dispuesto por la nueua cedula de vuestra real persona enbiando las dichas ynformaciones a vuestro Real consejo de Yndias para que se sirua hazerme mercedes//

\section{[f. 107v]}

conforme a la calidad de mi perssona meritos y seruicios del dicho mi padre e mios y para ello etc. el licenciado Antonio de Escobar don Francisco Altamirano. En La Plata a treinta de jullio de mill y quinientos e nouenta e seis años estando en audiencia publica los señores pressidente y oidores se presento esta peticion.

Los dichos señores mandaron dar traslado all fiscal de su magestad que estubo pressente Joan de Lossa.

El fiscal de su magestad dize que para la ymformacion de que se haze mencion se pueden resceuir los testigos de oficio y con el juramento que haze el dicho Francisco Altamirano se podia despachar el parescer que pide conforme a la real cedula. [al margen: decreto]

El corregidor del partido ymforme por escrito de lo que estos yndios pagan a su encomendero y enbie un traslado de la pasa [sic] en primero de agosto de mill y quinientos e nouenta y seis.

En La Plata a primero de agosto de mill e quinientos y nouenta e seis años los señores presidente y oidores proueyeron lo decretado //

\section{[f. 108r]}

de susso Joan de Lossa.

[al margen: peticion]

Muy poderosso señor don Francisco Altamirano vezino y regidor perpetuo desta ciudad cerca de la ymformacion que de oficio vuestra alteza a mandado hazer de los meritos y seruicios del capitan Joan Uelasquez Altamirano mi padre e los que yo e fecho a vuestra alteza digo que vuestro pressidente e oidores proueyeron decreto por el qual mandan que el corregidor de la prouincia de Atacama declare lo que rentan y dan de aprouechamientos los yndios que en la dicha prouincia tengo por encomienda y en lo que estan tassados como se contiene en el dicho decreto a que me refiero su tenor resumido de justicia se a de mandar se entienda con que el capitan Joan de Segura corregidor que fue de la dicha prouincia de Atacama antecessor del que al pressente es declare lo que por el dicho decreto se manda el qual esta en Potossi que es perssona que saue y a uisto mejor que el que es al pressente corregidor en la dicha prouincia lo que an dado de aprouechamientos los dichos yndios de mi encomienda //

\section{[f. $108 \mathrm{v}]$}

y lo que pueden dar por auer estado e ressidido quatro años continuos en la dicha prouincia y el que agora esta por corregidor en ella a muy poco tiempo que fue a la dicha prouincia e no tiene espiriencia desto demas de que ai mas de ciento y ueinte leguas a la dicha prouincia y caminos despoblados de suerte que en mucho tiempo no se pudiera traer la declaracion dell corregidor que agora esta en la dicha prouincia.

A vuestra alteza suplico atento a lo dicho declare entendersse el dicho decreto con el dicho capitan Joan de Segura que esta en Potossi para que haga 
la declaracion de todo lo que por el dicho decreto se manda e para ello se me despache vuestra real prouission para que ante qualesquiera justicia de la uilla de Potossi el susso dicho haga la dicha declaracion y fecha se enbie a esta real audiencia para que se ponga con los demas desta causa pido justicia etc. el licenciado Antonio de Escobar don Francisco Altamirano. //

\section{[f. 109r]}

En La Plata tres de agosto de mil y quinientos e nouenta y seis años en audiencia publica ante los señores pressidente y oydores della se presento esta peticion.

Los dichos señores mandaron dar traslado all fiscal de su magestad y con lo que dixere o no se traiga all acuerdo y estuuo presente el fiscal de su magestad Joan de Lossa.

El fiscal de su magestad dize que tiene pedido en esta caussa lo que conuiene.

[al margen: decreto]

Traigansse los autos en siete de agosto de mill e quinientos y nouenta e seis.

En la ciudad de La Plata en siete dias del mes de agosto de mill e quinientos y nouenta e seis años los señores presidente e oidores desta real audiencia proueyeron lo decretado de susso Joan de Lossa.

[al margen: decreto]

El corregidor de Potossi tome su declaracion all capitan Joan de Segura y la enbie luego cerrada y sellada a esta audiencia.

En la ciudad de La Plata a ocho dias del mes de agosto de nouenta y seis //

\section{[f. 109v]}

los señores pressidente e oydores en acuerdo de justicia proueyeron lo decretado de susso Joan de Lossa.

Don Phelipe por la gracia de Dios Rey de Castilla [...] a uos el maese de campo Alonsso Garcia Remon nuestro corregidor de la prouincia de Los Charcas que residis en la villa ymperial de Potossi salud y gracia saued que auiendo pedido don Francisco Altamirano vezino feudatario de la ciudad de La Plata en quien estan encomendados los yndios de la prouincia de Atacama y puertos della en la nuestra audiencia //

\section{[f. 110r]}

y cancilleria real que resside en la ciudad de La Plata del Piru ante el nuestro pressidente y oidores della se le resciuiesse ymformacion de los seruicios que el y Joan Uelasquez su padre nos an hecho y esta fuese de oficio conforme a nuestra real cedula se le mando resceuir y se a hecho y para poder enterarnos para el parescer que an de dar el pressidente e oydores de la dicha nuestra audiencia para que conforme a ello el dicho don Francisco Altamirano reciua merced en nuestra real perssona es nescesario y conuiene ser ymformados de lo que los dichos yndios de Atacama pagan a su encomendero conforme a la tassa sobre lo qual se proueyo el decreto.

[al margen: decreto]

que se sigue. El corregidor del partido ymforme por escrito de lo que estos yndios pagan a su encomendero y enbien traslado de la tassa. En La Plata a primero de agosto de mill e quinientos y nouenta y seis años los señores pressidente y oidores proueyeron lo decretado de suso Joan de Lossa.

Y el dicho don Francisco Altamirano presento una peticion del tenor siguiente: //

\section{[f. 110v]}

Muy poderosso señor don Francisco Altamirano vezino y regidor perpetuo desta ciudad cerca de la ymformacion que de oficio vuestra alteza a mandado hazer de los meritos y seruicios del capitan Joan Uelasquez Altamirano mi padre e los que yo e fecho e vuestra alteza digo que vuestro pressidente e oidores proueyeron decreto por el qual mandan que el corregidor de la prouincia de Atacama declare lo que rentan y dan de aprouechamientos los yndios que en la dicha prouincia tengo por encomienda y en lo que estan tassados como se contiene en el dicho decreto a que me refiero su tenor resumido de justicia se a de mandar se entienda con que el capitan Joan de Segura corregidor que fue de la dicha prouincia de Atacama antecessor del que al pressente es declare lo que por el dicho decreto se manda el qual esta en Potossi que es perssona 
que saue y a uisto mejor que el que es al pressente corregidor en la dicha prouincia lo que an dado de aprouechamientos los dichos yndios //

\section{[f. 111r]}

de mi encomienda e lo que pueden dar por auer estado e ressidido quatro años continuos en la dicha prouincia y el que agora esta por corregidor en ella a muy poco tiempo que fue a la dicha prouincia e no tiene espiriencia desto demas de que ai mas de ciento y veinte leguas a la dicha prouincia y caminos despoblados de suerte que en mucho tiempo no se pudiera traer la declaracion dell corregidor que agora esta en la dicha prouincia.

A vuestra alteza suplico atento a lo dicho declare entendersse el dicho decreto con el dicho capitan Joan de Segura que esta en Potossi para que haga la declaracion de todo lo que por el dicho decreto se manda e para ello se me despache vuestra real prouission para que ante qualesquiera justicia de la uilla de Potossi el susso dicho haga la dicha declaracion y fecha se enbie a esta real audiencia para que se ponga con los demas desta causa pido justicia etc. el licenciado Antonio de Escobar don Francisco Altamirano.

\section{Y bisto por el dicho nuestro pressidente //}

\section{[f. 111v]}

y oidores fue acordado que deuiamos mandar dar esta nuestra carta en la dicha razon e tubimoslo por bien porque nos mandamos que hagais parescer e traer ante nos all dicho capitan Joan de Segura nuestro corregidor que fue de la dicha prouincia de Atacama y resciuais del juramento en forma deuida de derecho y hareis que diga e declare lo que supiere acerca de lo que los dichos yndios de Atacama an dado e dan de tributo a su encomendero e lo que pueden dar todo ello con distincion y claridad y ansi mismo a de declarar en lo que estan tassados por la tassa para que nos seamos enterado de todo conforme all dicho decreto y peticion suso yncorporada y la dicha declaracion originalmente cerrada y sellada en publica forma e manera que haga fee la enuiareis a la dicha nuestra audiencia lo qual ansi cumplid so pena de la nuestra merced y de quinientos pessos de oro para la nuestra camara dada en La Plata a doze dias del mes de agosto de mil e quinientos y nouenta y seis años el licenciado Cepeda el lcenciado Lopidana el licenciado Bernardino de Albornoz //

\section{[f. 112r]}

el licenciado Roxo yo Joan de Lossa Barahona escriuano de camara del catholico rey nuestro señor la fize escreuir por su mandado con acuerdo de su pressidente y oydores registrada Martin de Galarça chanciller Luis de Rojas.

En la villa de Potossi a veinte e dos de agosto de mill y quinientos e nouenta e seis años ante el maesse de campo Alonsso Garcia Ramon corregidor e Justicia mayor en esta dicha uilla e prouincia por su magestad parescio don Francisco Altamirano e pressento la real prouission susso conthenida de la real audiencia de la ciudad de La Plata e pidio su cumplimiento della e que el capitan Joan de Segura declare por el tenor della como se manda.

E por el dicho corregidor vista la tomo en sus manos beso e pusso sobre su cabeça con el acatamiento deuido como a carta e prouission de su Rey e señor natural a quien la diuina magestad conserue y guarde en su santo seruicio con el acrecentamiento de mayores reynos e señorios e que esta presto de la guardar y cumplir segun como por ella su magestad manda y en su cumplimiento mando parescer ante su merced el dicho capitan Joan de Segura //

\section{[f. 112v]}

que esta presto de tomar la declaracion que por la dicha real prouission se manda y ansi lo proueyo mando e firmo Alonsso Garcia Ramon ante mi Joan de Vergara escriuano publico.

[al margen: declaracion]

En la villa ymperial de Potossi jueves veinte e dos dias del mes de agosto de mil y quinientos e nouenta y seis años en cumplimiento de la dicha real prouission obedecida por el dicho corregidor con su asistencia yo el pressente escriuano tome e resceui juramento por Dios nuestro señor en forma deuida [a] derecho del capitan Joan de Segura e auiendo prometido de dezir uerdad y siendo preguntado por el tenor de la dicha real prouission e auiendola leydo y entendido el efeto della:

Dixo que saue que los dichos yndios hasta agora no an pagado tasa ninguna ni el lo pudo cobrar en el tiempo que fue corregidor del dicho partido de Atacama porque hasta entonces ellos no lo auian pagado y que saue y entiende que reducidos y puestos 
en razon podran muy bien pagar los dichos yndios ocho pesos corrientes cada uno en cada un año y que cree que uissitados habra en la dicha prouincia de Atacama y sus puertos ochocientos yndios //

\section{[f. 113r]}

poco mas o menos y que anssi mismo saue que aunque en tiempo del pressidente Ramirez aquellos yndios se tassaron la dicha tasa se hizo sin uissita ni sauer los que eran solo con yntento de que los dichos yndios tuuiessen doctrina como paresce por la dicha tassa a que se refiere y ansi mismo se refiere a los autos e diligencias que hizo siendo tal corregidor para la cobrança de los dichos tributos que originalmente estan en su residencia y esto es lo que saue e la uerdad para el juramento que hizo e lo firmo de su nombre e dixo ser de hedad de quarenta años poco mas o menos e lo firmo el dicho corregidor Alonso Garcia Ramon Joan de Segura ante mi Joan de Vergara escriuano publico.

[al margen: decreto]

\section{Lleuese al señor fiscal.}

En La Plata en ueinte e nueue dias del mes de agosto de mill e quinientos e nouenta y seis años los señores pressidente e oydores en acuerdo de justicia proueyeron lo decretado de susso Joan de Lossa.

El fiscal de su magestad dize que se puede dar parescer all dicho don Francisco Alta- //

\section{[f. 113v]}

Altamirano [sic] teniendo atencion a lo que jura e declara Joan de Segura testigo que en esta caussa a declarado.

\section{[al margen: peticion]}

Muy poderosso señor don Fernando Altamirano clerigo presbitero hijo legitimo de Joan Uelasquez Altamirano e de doña Ysabel Brauo digo que en esta real audiencia el dicho Joan Uelasquez mi padre en conformidad de la cedula real de su magestad ofrescio ynformacion de sus muchos y calificados seruicios que a vuestra real perssona hizo en estos reinos y en otras partes y lo propio ofrescio don Francisco Altamirano mi hermano hijo anssi mismo legitimo de los dichos mis padres que en continuacion dellos a hecho en estos reinos en vuestro real seruicio de todo lo qual se resciuio ymformacion por el dicho orden con mucho numero de testigos los cuales conforme a derecho y a que el dicho mi padre no fue galardonado ni remunerado conforme a ellos ni resciuio merced para augmento suyo para su patrimonio onrras y preheminencias que sus hijos pudiessen subceder en ellas por cuya caussa de justicia yo //

\section{[f. 114r]}

como tal su hijo en mi se subrrogan los dichos seruicios para el premio que mi padre merescio se me de a mi por el estado eclesiastico que professo en el qual ansi mismo e biuido y procedido uirtuossa y exemplarmente dando buena quenta de los cargos de vicario y curatos que por los obispos y sede bacante se me an encomendado e dado como paresce por estos recaudos que pressento con el parescer del dicho cauildo sede bacante para que uisto por buestra alteza todo e ynformaciones de mi padre y hermano se sirua por ellos dar su parescer a su majestad en conformidad de la dicha cedula real me haga merced de una dignidad o preuenda en esta santa yglesia que como hijo e natural desta ciudad sea preferido a otros pues de derecho y ley del reino lo soy que todo se sirua vuestra alteza de considerar para esta merced que suplico.

[al margen: Item]

A vuestra alteza pido y suplico mande uer las dichas ymformaciones que de oficio se an fecho por el dicho mi padre y mi hermano y las que yo agora pressento con el parecer del dicho cauildo y en consequencia vuestra //

\section{[f. 114v]}

alteza se sirua de ynformar a vuestra real perssona de los meritos de las dichas prouanças y de su calidad y las de los dichos mis padres y de como tengo a la dicha Ysabel Brauo mi madre con quatro hermanas donzellas donde parescer se me haga meçed de una dignidad o canongia de la santa yglesia desta ciudad proueiendolo ansi en la conformidad dicha resciuiendo ymformaçion si fuere nescesario de como tengo madre y hermanas como esta dicho y de lo demas que conuenga de justicia que pido y en ello resciuire merced etcetera el doctor Francisco Perez don Fernando Altamirano.

La Plata a quatro de febrero de mill e seiscientos e ocho años estando en acuerdo de juzticia los señores 
pressidente e oydores desta real audiencia se metio esta peticion con el parescer del dean e cabildo de la yglesia cathedral deste obispado sede bacante e de mas recaudos contenidos en ella.

[al margen: decreto]

Los dichos señores mandaron que todo se sume con la ymformacion de los seruicios de Juan Velasquez
Altamirano e traiga al acuerdo Diego de Labona de Ayala.

[El documento continúa con los méritos de Fernando Altamirano sin agregar otra información sobre la encomienda de Atacama. Nota del transcriptor]. 